(C) 2021, The Authors. Published by Elsevier Inc. and Fass Inc. on behalf of the American Dairy Science Association ${ }^{\circledR}$. This is an open access article under the CC BY-NC-ND license (http://creativecommons.org/licenses/by-nc-nd/4.0/).

\title{
ADSA Foundation Scholar Award: New frontiers in calf and heifer nutrition-From conception to puberty
}

\author{
J. K. van Niekerk, ${ }^{1}$ A. J. Fischer-Tlustos, ${ }^{1}$ J. N. Wilms, ${ }^{1,2}$ K. S. Hare, ${ }^{1}$ A. C. Welboren, ${ }^{1}$ A. J. Lopez, ${ }^{1}$ T. T. Yohe, ${ }^{1}$ \\ L. R. Cangiano, ${ }^{1}$ L. N. Leal, ${ }^{2}$ and M. A. Steele ${ }^{1 *}$ \\ ${ }^{1}$ Department of Animal Biosciences, Animal Science and Nutrition, University of Guelph, Guelph, ON, Canada N1G 1Y2 \\ ${ }^{2}$ Trouw Nutrition Research and Development, PO Box 299, 3800 AG, Amersfoort, the Netherlands
}

\begin{abstract}
Dairy calf nutrition is traditionally one of the most overlooked aspects of dairy management, despite its large effect on the efficiency and profitability of dairy operations. Unfortunately, among all animals on the dairy farm, calves suffer from the highest rates of morbidity and mortality. These challenges have catalyzed calf nutrition research over the past decade to mitigate high incidences of disease and death, and improve animal health, growth, welfare, and industry sustainability. However, major knowledge gaps remain in several crucial stages of development. The purpose of this review is to summarize the key concepts of nutritional physiology and programming from conception to puberty and their subsequent effects on development of the calf, and ultimately, future performance. During fetal development, developmental plasticity is highest. At this time, maternal energy and protein consumption can influence fetal development, likely playing a critical role in calf and heifer development and, importantly, future production. After birth, the calf's first meal of colostrum is crucial for the transfer of immunoglobulin to support calf health and survival. However, colostrum also contains numerous bioactive proteins, lipids, and carbohydrates that may play key roles in calf growth and health. Extending the delivery of these bioactive compounds to the calf through a gradual transition from colostrum to milk (i.e., extended colostrum or transition milk feeding) may confer benefits in the first days and weeks of life to prepare the calf for the preweaning period. Similarly, optimal nutrition during the preweaning period is vital. Preweaning calves are highly susceptible to health challenges, and improved calf growth and health can positively influence future milk production. Throughout the world, the majority of dairy calves rely on milk replacer to supply adequate
\end{abstract}

Received December 7, 2020

Accepted March 16, 2021.

*Corresponding author: masteele@uoguelph.ca nutrition. Recent research has started to re-evaluate traditional formulations of milk replacers, which can differ significantly in composition compared with whole milk. Transitioning from a milk-based diet to solid feed is critical in the development of mature ruminants. Delaying weaning age and providing long and gradual step-down protocols have become common to avoid production and health challenges. Yet, determining how to appropriately balance the amount of energy and protein supplied in both liquid and solid feeds based on preweaning milk allowances, and further acknowledging their interactions, shows great promise in improving growth and health during weaning. After weaning and during the onset of puberty, heifers are traditionally offered high-forage diets. However, recent work suggests that an early switch to a high-forage diet will depress intake and development during the time when solid feed efficiency is greatest. It has become increasingly clear that there are great opportunities to advance our knowledge of calf nutrition; yet, a more concentrated and rigorous approach to research that encompasses the long-term consequences of nutritional regimens at each stage of life is required to ensure the sustainability and efficiency of the global dairy industry.

Key words: calf, heifer, nutrition, development

\section{INTRODUCTION}

The overall goal of rearing calves and replacement heifers is to raise healthy and nutritionally efficient animals in a humane and cost-effective manner. Most rearing strategies aim to reduce the age at first calving to lessen nonproductive days, while ensuring that heifers achieve sufficient frame size and organ development without compromising milk production (Heinrichs et al., 2017; Van Amburgh et al., 2019; Erickson et al., 2020). Over the past 2 decades, knowledge of developmental and nutritional programming of young livestock animals has advanced (Soberon et al., 2012; Bartol et al., 2013; Gelsinger et al., 2016). This research suggests that several key windows of developmental program- 
ming (fetal, neonatal, preweaning, weaning, pre- and postpubertal) exist, in which nutritional management in utero to first calving may contribute to the overall development of the calf, and ultimately, to improved future milk production (Berry et al., 2008; Heinrichs et al., 2017; Kertz et al., 2017). Showcasing the positive, long-term outcomes of improving early-life growth and health has stimulated greater interest in calf research, with the amount of research dedicated to heifer nutritional management doubling over the past decade (Heinrichs et al., 2017). Despite growing interest, 10 to $15 \%$ of heifers born do not reach first calving (De Vries and Marcondes, 2020), demonstrating that there is still significant room to improve heifer management strategies. These strategies can be largely improved by optimizing nutritional management, which has the potential to benefit the dairy industry via improved production, efficiency, health, and animal welfare.

Developmental plasticity is defined as the ability for the same genotype to produce different phenotypes through epigenetic regulation (Hochberg et al., 2011). In animals, developmental plasticity begins, and is most dynamic, at conception, which suggests that the prenatal and early postnatal periods have the greatest potential for nutritionally programming the calf (Fig- ure 1; Bartol et al., 2013). Despite this critical window, this field has only recently gained research interest, as emerging evidence suggests that milk production potential can be initially programmed in utero, signaled by nutritional or environmental changes experienced by the dam (Dahl et al., 2019; Carvalho et al., 2020; Van Eetvelde and Opsomer, 2020). Postnatal, developmental programming may be influenced by early-life nutritional strategies, including management of colostrum and preweaning nutrient intake. During early life, it is well known that colostrum and milk intake play key roles in nutritional programming and can have subsequent effects on growth (Rauprich et al., 2000; Moallem et al., 2010), gut development (Hammon and Blum, 2002; Fischer et al., 2019) and future milk production (Faber et al., 2005; Soberon et al., 2012).

The preweaning and weaning periods have been the most studied (Figure 1) but remain among the most challenging stages of a calf's life, as reflected by high morbidity and mortality rates (USDA, 2016; Urie et al., 2018b). Calves are highly susceptible to disease during this period due to a combination of factors, including failed passive transfer of immunity (Shivley et al., 2018; Renaud et al., 2020), social stress, and environmental and housing conditions (Wilcox et al., 2013; Roland

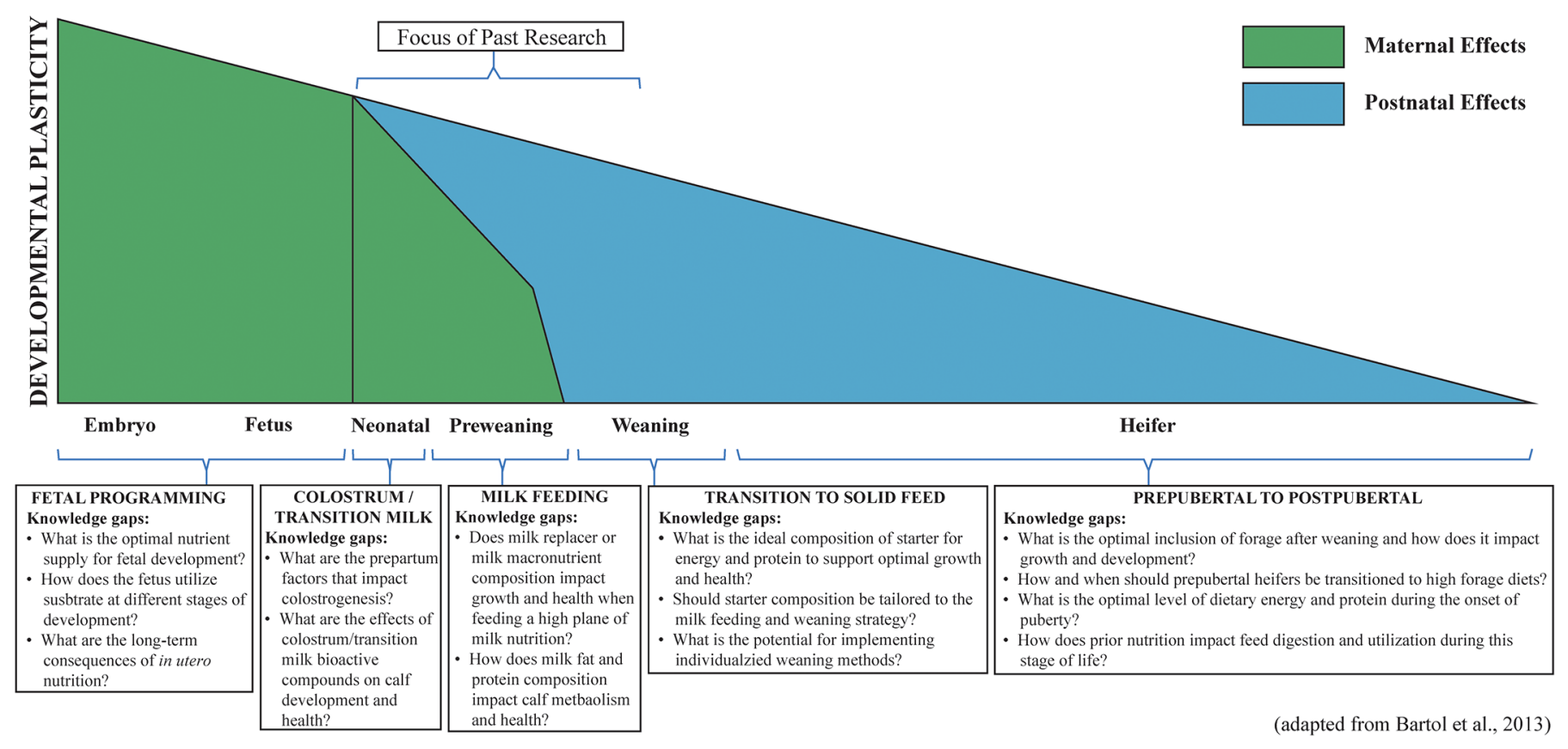

Figure 1. Several key windows of developmental programming (embryo, fetus, neonatal, preweaning, weaning, pre- and postpubertal) exist throughout the first years of a heifer's life. As the calf ages, developmental plasticity - the degree by which environmental or nutritional conditions influence heifer development and phenotype - gradually decreases. During each developmental window, varying levels of maternal (green) and postnatal (blue) effects influence the heifer phenotype. These maternal and postnatal effects largely consist of dam nutrition during the embryonic and fetal periods and heifer nutrition from the neonatal to pubertal stage. Fundamental knowledge gaps related to nutritional management in utero to puberty that may contribute to the overall development of the calf and future productivity are described in text boxes below each developmental window. 
et al., 2016). An estimated 5\% of US dairy calves die during the preweaning period, and $33.8 \%$ experience a health disorder before weaning (Urie et al., 2018b). Digestive disorders remain the most common cause of morbidity and mortality for dairy calves, accounting for over half of reported illnesses and one-third of deaths (Urie et al., 2018b; Winder et al., 2018). Many health disorders, including diarrhea, experienced by calves during the preweaning and weaning periods can often be prevented or mitigated through well-developed nutritional management programs (Ollivett et al., 2012; Ballou, 2012). Additionally, optimizing nutritional strategies during the preweaning period can have significant economic benefits, as they not only directly affect mortality rate, disease susceptibility, and growth rate during the preweaning period, but also milk production later in life (Soberon et al., 2012; Soberon and Van Amburgh, 2013; Gelsinger et al., 2016).

There is a plethora of research investigating optimal solid feed programs for young calves and calves during weaning (Figure 1). Solid feed plays an important role in nutritional programming, as improved solid feed intake contributes to increased preweaning ADG, which positively influences first-lactation milk production (Soberon et al., 2012; Gelsinger et al., 2016). Moreover, research conducted during the prepubertal-to-first-calving period has focused on nutritional management that ensures adequate growth and development (Heinrichs et al., 2017; Van Amburgh et al., 2019; Erickson et al., 2020). There is currently a lack of research pertaining to nutritional management from the postpubertal stage to first calving and its effect on efficiency and productivity during lactation. Therefore, this narrative review will highlight some of the key nutritional contributors that influence heifer calf development at different life stages. These include nutritional physiology during the in utero, neonatal, preweaning, weaning, and prepubertal and pubertal stages of life, with key knowledge gaps highlighted and discussed for each life stage.

\section{PRENATAL DEVELOPMENT AND NUTRITION}

Prenatal programming is the process by which the embryo or fetus adapts to changes in the uterine environment reflecting alterations in the maternal environment (Reynolds et al., 2019). Phenotypic changes can be mediated by epigenetic mechanisms, such as differential gene expression without changes in the genetic code (Reynolds et al., 2019), direct effects on organ or tissue development in utero (Du et al., 2010), or a combination of both. These differences can be observed as early as the neonatal period (Alharthi et al., 2019; Haisan et al., 2019) or may appear later in life during lactation (González-Recio et al., 2012; Van Eetvelde et al., 2017; Carvalho et al., 2020). Factors that program prenatal development in dairy calves include maternal age, malnutrition, metabolic and oxidative disturbance, heat stress, dry period length, and photoperiod (Van Eetvelde and Opsomer, 2017, 2020; Abuelo, 2020). The gestational onset, duration of time, and degree of severity of the prenatal programmer determine the signal strength to the fetus and the resulting phenotypic changes. Ultimately, in-depth knowledge of bovine fetal development and nutrient requirements is needed to understand how adverse programming effects can be prevented and to ensure potential benefits from epigenetic changes.

\section{Gestational Nutrient Intake and Fetal Requirements}

The NRC (2001) model estimates energy and protein requirements for gestating dairy cattle based on serial slaughter studies from 190 to $270 \mathrm{~d}$ postconception (House and Bell, 1993; Bell et al., 1995). Using the equations derived from these studies and considering that most fetal growth occurs between mid to late gestation, most nutrient requirements are presumed to be zero for the fetus up to $190 \mathrm{~d}$ postconception (NRC, 2001). Additionally, some mineral and vitamin requirements (sulfur, cobalt, iodine, selenium, and vitamin D) are not assumed to increase during gestation and, thus, are not factored within the model (NRC, 2001). Metabolizable energy and MP requirements after $190 \mathrm{~d}$ postconception are empirically modeled and corrected by their respective efficiencies of use (0.14 and 0.33 ; Ferrell et al., 1976; Bell, 1995) for gestation. Though estimates obtained using this approach are reasonably close to observed values during late gestation (Bell, 1995), there are some limitations to this method.

Predominantly, gestational nutrient requirements before $190 \mathrm{~d}$ postconception should not be disregarded. Sguizzato et al. (2020) determined that the energy requirement for pregnancy was different from zero at $70 \mathrm{~d}$ postconception and onwards in Holstein $\times \mathrm{Gyr}$ dams. Slightly elevated maternal glucose concentrations $(+13 \%)$ obtained through exogenous glucose infusion reduce conceptus length, width, and area $7 \mathrm{~d}$ after embryo transfer (Leane et al., 2018), demonstrating that the gravid uterus has a high sensitivity to fluctuating metabolites during early gestation. As peak milk production typically coincides with breeding and conception, homeorhetic nutrient partitioning toward lactation will alter the supply of metabolites available to the developing fetus and potentially program fetal development and postnatal insulin sensitivity (Kamal et al., 2014; 2015). Maternal metabolic health challenges can also program lactation characteristics in female progeny (Carvalho et al., 2020). Early maternal 
malnutrition can alter fetal development (Duarte et al., 2013; Rotta et al., 2015; Gionbelli et al., 2018), although in utero compensatory growth during the later stages of gestation is possible (Pillai et al., 2017; Copping et al., 2020). The divergent in utero growth could have consequences for future progeny development without alterations in gross fetal development being apparent at birth.

Another concern is that framing fetal nutrient requirements in the context of maternal $\mathrm{ME}$ or $\mathrm{MP}$ requirements during gestation (NRC, 2001) simplifies which substrates are needed by the fetus for proper development. Glucose, lactate, and AA are the primary fetal oxidative substrates (Bauman and Currie, 1980; Bell, 1995); however, it is unknown how shifting maternal ME supply or source at different stages of gestation influences the availability of energetic substrates for oxidation or energy deposition in fetal tissue. Haisan et al. (2019) found that increasing dry period dietary starch content from 14.0 to $26.1 \%$ DM increased insulin area under the curve and maximum insulin concentration during an intravenous glucose tolerance test in neonatal calves. It is unclear whether total dietary energy content or the form of dietary energy supplied programmed neonatal and preweaning metabolic responses in this study; however, late-gestation maternal insulin resistance is correlated with metabolic traits in preweaned dairy calves (Kawashima et al., 2016; Hasegawa et al., 2019). Mediating the degree of insulin resistance experienced during late gestation might improve metabolic responses in preweaning calves, although it is still unclear how differing dietary energy content or source during early or mid-gestation would influence fetal development and postnatal metabolism.

The current NRC (2001) model reasonably predicts the MP requirement for conceptus development during late gestation (Bell, 1995); however, the model likely underestimates late-gestation MP requirements because it does not consider the MP required for mammogenesis ( $120 \mathrm{~g}$ of $\mathrm{MP} / \mathrm{d}$; Bell et al., 2000), consequently causing a late gestation MP deficit. A recent meta-analysis validated this concept for primiparous heifers, demonstrating linearly improved production responses when heifers were fed up to $1,100 \mathrm{~g}$ of $\mathrm{MP} / \mathrm{d}$ during late gestation (Husnain and Santos, 2019). More conservative responses were reported with multiparous cattle (Husnain and Santos, 2019), suggesting that MP requirements may be adequately modeled for lategestation multiparous cows. However, it is crucial to acknowledge that this meta-analysis focused on cow production parameters without evaluating the influence of maternal MP supply on calf performance. In beef cattle, protein restrictions reduced plasma glucose and leptin and increased cortisol concentrations of calves at birth (LeMaster et al., 2017), demonstrating that maternal protein deficits can affect offspring during the neonatal period. To our knowledge, the influence of prepartum MP under- or oversupply on the development of dairy calves has not been evaluated. Although MP-focused feeding does improve predictions regarding the adequacy of protein supply compared with CPfocused feeding, cattle still require the constituents of MP (i.e., metabolizable AA) for optimal performance (Lean et al., 2018; Nichols et al., 2019). Preliminary evidence suggests that late-gestation rumen-protected methionine supplementation has profound effects on placental metabolism and calf development when diets already oversupply MP (Alharthi et al., 2018, 2019; Batistel et al., 2018, 2019; Elolimy et al., 2019). Although these studies strongly implicate methionine as a limiting AA during late gestation, methionine supplementation caused imbalanced MP supply between treatments and increased DMI by $1.2 \mathrm{~kg} / \mathrm{d}$ (Batistel et al., 2017); therefore, responses are confounded by both MP and nutrient intake.

\section{Future Directions}

Fetal development is complex and dynamic throughout all stages of gestation, and phenotypic responses in dairy calves will depend on the timing, duration and severity of the prenatal programmer. As the current NRC (2001) model does not consider the maternal requirements for gestation before $190 \mathrm{~d}$, future models should account for the additional requirements for pregnancy before $190 \mathrm{~d}$ of gestation to ensure that nutrient supply optimizes fetal development. Dairy cows experience a negative energy balance in early pregnancy and are susceptible to overconditioning in late gestation, which may influence the growing fetus. Further research is needed to understand how maternal energy or protein supplies and sources modulate the availability of substrates for fetal metabolism. Additionally, the adequacy of protein supply and the role of specific metabolizable AA on the efficiency of protein utilization for gestation requires further evaluation. An improved understanding of substrate supply and utilization by the developing fetus will enable us to predict adverse or positive developmental programming outcomes in dairy calves.

\section{NEONATAL PERIOD}

After birth, neonatal calves require diligent care and management as their undeveloped immune system causes an inherent susceptibility to environmental pathogens. They depend on the timely consumption of colostrum to provide humoral immunity until their adaptive immune system becomes fully developed and 
active (Weaver et al., 2000). Calves establish humoral immunity via colostrum by absorbing intact and functional colostral immunoglobulins, known as the transfer of passive immunity (TPI; Dunn et al., 2017). Improper colostrum feeding can compromise the calf's capacity to absorb adequate quantities of immunoglobulins, leading to an increased incidence of morbidity. Twelve and $24 \%$ of dairy calves in the United States (Shivley et al., 2018) and Canada (Renaud et al., 2020), respectively, suffer from failed TPI based on the traditional dichotomous standard of $10 \mathrm{mg}$ of $\mathrm{IgG} / \mathrm{mL}$ in serum (Quigley, 2004) or a serum total protein value $\leq 5.2 \mathrm{~g} /$ $\mathrm{dL}$ at $24 \mathrm{~h}$ of age (Buczinski et al., 2018). However, new serum $\operatorname{IgG}$ thresholds (poor: $\leq 10 \mathrm{~g}$ of $\operatorname{IgG} / \mathrm{L}$; fair: $>10 \mathrm{~g}$ of IgG/L; good: $>18 \mathrm{~g}$ of IgG/L; excellent: $>25$ $\mathrm{g}$ of $\operatorname{IgG} / \mathrm{L}$ ) have been established and are currently being recommended to promote calf health and survival (Lombard et al., 2020). Consequently, there will be a push for dairy producers to improve colostrum management to ensure neonatal calves achieve and surpass "good" serum IgG thresholds.

In terms of TPI, the components of a successful colostrum management program - quality, quantity, timeliness of colostrum feeding, low bacterial contamination, and colostrum source - have recently been reviewed in depth (Godden et al., 2019; Fischer-Tlustos et al., 2021). Thus, this section will largely focus on prepartum management strategies affecting colostrum composition, as well as the beneficial effects that colostrum may have on calf development through its myriad of bioactive components.

\section{Cow, External, Nutritional, and Environmental Factors Affecting Colostrum Composition}

Colostrum composition and quality, specifically IgG concentration, can vary greatly among cows and between farms (Morrill et al., 2012; Conneely et al., 2013). In general, colostrum composition can be affected by parity number, dry period length, colostrum volume, breed of the dam (Weaver et al., 2000), vaccination protocols (Dunn et al., 2017), disease exposure, diet (Tsioulpas et al., 2007; Mann et al., 2016), animal variation (Parrish et al., 1950), onset of colostrogenesis (Baumrucker and Bruckmaier, 2014), individual farm variation (Gulliksen et al., 2008), and endocrine regulation (Guy et al., 1994). Dry period length and temperature-humidity index have been shown to have only minor associations with colostrum quality (Zentrich et al., 2019).

Dairy cows are traditionally dried off $60 \mathrm{~d}$ before expected parturition and fed a controlled-energy diet throughout the whole dry period (NRC, 2001). However, researchers have proposed that dry period energy density may affect IgG content in first-milking colos- trum (Mann et al., 2016; Dunn et al., 2017). Mann et al. (2016) found that feeding $150 \%$ of ME requirements during the dry period reduced colostral IgG concentration compared with feeding a control diet formulated to meet $100 \%$ of ME requirements. However, it is important to note that the diets in that study (Mann et al., 2016) only provided 91 and $123 \%$ of ME requirements in the control and treatment groups, respectively, during the week before calving. The energy restriction in the control group immediately before calving may have contributed to the differences in colostral IgG concentrations, as opposed to the energy oversupply in the treatment group. Aside from the aforementioned study, the majority of prepartum environmental and nutritional practices mentioned have not been investigated thoroughly and, as a result, concise and accurate recommendations on how to properly manage prepartum factors to improve colostrum quality (in terms of IgG) remain unclear (Zentrich et al., 2019).

\section{Effect of Colostrum Components on the Neonatal Calf}

Colostrum has a high fat content $[5.7-6.4 \%$ vs. $4.3 \%$ in whole milk (WM); Dunn et al., 2017; Fischer-Tlustos et al., 2020] that is readily absorbed (Gooden et al., 1971) to support thermoregulation and the rapid metabolism of a newborn calf (Vermorel et al., 1983). Colostrum also contains a distinct fatty acid (FA) profile compared with WM, with higher levels of polyunsaturated and n-3 FA, and lower concentrations of saturated short-chain FA (Contarini et al., 2014; McGrath et al., 2016; O'Callaghan et al., 2020). Recent work indicated that feeding colostrum replacer supplemented with rumen-protected sodium butyrate $(2.5 \% \mathrm{wt} / \mathrm{vol})$ negatively influenced TPI (Hiltz and Laarman, 2019). Similarly, this result was observed with isobutyrate supplementation (Baumwart et al., 1977). The concentration of butyrate in colostrum is approximately half that of d-5 milk (O'Callaghan et al., 2020), possibly to avoid interference with gut closure, allowing for a prolonged period of intestinal hyperpermeability and facilitating TPI (Skrzypek et al., 2018). Conversely, feeding calves colostrum supplemented with $60 \mathrm{~mL}$ of a 1:1 mixture of fish and flaxseed oils (with $200 \mathrm{mg}$ of $\alpha$-tocopherol) high in n-3 FA (n-6:n-3 = 2.6:1) improved antioxidant status and reduced the accumulation of reactive oxygen and nitrogen species compared with calves fed a control colostrum (n-6:n-3 = 3.2:1; Opgenorth et al., 2020). However, it is important to note that the design of that study did not allow the authors to discern whether the observed effects were due to elevated n-3 FA, $\alpha$-tocopherol, or their combination. Neonatal calves are subjected to high levels of oxida- 
tive stress and a prolonged state of inflammation due to several factors, including dam stress before calving, dystocia, the onset of oxygen respiration, and the metabolic demands of adapting to the ex utero environment (Saugstad, 2003; Hulbert and Moisa, 2016; Ling et al., 2018). Elevated n-3 FA in colostrum (O'Callaghan et al., 2020) increases the pool of precursors used to produce anti-inflammatory compounds, thereby improving antioxidant capacity (Mavangira and Sordillo, 2018) and may counteract the oxidative stress experienced during the initial weeks of life.

In contrast to fat, colostral lactose content is $1.8 \times$ lower than that of WM (Fischer-Tlustos et al., 2020). Yet, colostrum contains 15 to 72 times greater concentrations of the primary acidic oligosaccharides (OS) than WM (Fischer-Tlustos et al., 2020). These OS are largely composed of a lactose core at their reducing end and are elongated by one or more sialic acid residues at the terminal end of the lactose molecule and can profoundly resist the low $\mathrm{pH}$ of the upper gastrointestinal tract and hydrolysis by pancreatic and mucosa-bound glycosidases (Engfer et al., 2000). Almost 50\% of colostral OS are present in the colon of neonatal calves $12 \mathrm{~h}$ after feeding, demonstrating that the majority of OS reach the colon of the calf intact (Fischer et al., 2018). In vitro work has shown that the major OS in bovine colostrum and WM promote the growth of the beneficial bacterium Bifidobacterium in the intestinal tract (Yu et al., 2013) by inducing a substantial transcriptional response, enhancing its adhesion to enterocytes, and thus colonization in the neonatal gut (Kavanaugh et al., 2013). Importantly, IgG from bovine colostrum is highly glycosylated with sialic acid (Feeney et al., 2019), potentially derived from colostrum OS, which may interact directly with the IgG receptor site or indirectly stabilize the conformation of the receptor molecule (Gill et al., 1999), thereby providing a mechanism by which colostrum OS might influence IgG absorption in neonates. However, it is currently unclear if the specific glycosylation of IgG in colostrum directly facilitates $\operatorname{Ig} G$ absorption in neonatal dairy calves.

Aside from the aforementioned bioactive components, colostrum contains an abundance of nonnutritive components that can influence the physiology and development of the newborn calf. For instance, colostrum contains microRNAs (miRNA) packaged in exosomes and microvesicles that are highly resistant to acidic environments and likely reach the small intestine in a biologically active state (Izumi et al., 2014; Benmoussa et al., 2016; Van Hese et al., 2020). Recent research in calves has demonstrated that of the 10 most highly expressed miRNA in the calf intestine, 6 were greater in colostrum compared with WM (Chen et al., 2010; Liang et al., 2014). The wide array of miRNA in co- lostrum are hypothesized to positively affect development of the intestine and immune system regulation (Van Hese et al., 2020). Fresh colostrum also contains large amounts of maternal leukocytes (Godden et al., 2012) that can be detected in the blood, lymph nodes, and Peyer's patches of newborn calves after colostrum ingestion (Aldridge et al., 1998; Liebler-Tenorio et al., 2002; Reber et al., 2006). Maternal leukocytes in fresh colostrum have been implicated in reducing anemia and incidences of diarrhea (Novo et al., 2017). In addition, feeding whole versus cell-free colostrum increases vaccine responses in young calves (Langel et al., 2016), suggesting that the transfer of maternal cells in colostrum has both short- and long-term effects on the development of the calf's immune system. In addition to the aforementioned bioactive compounds, colostrum possesses supraphysiological concentrations of growth factors, hormones, nucleotides, and antimicrobial compounds that have been largely overlooked (see reviews by Blum and Hammon., 2000; McGrath et al., 2016; Fischer-Tlustos et al., 2021), compared with IgG, in the past.

\section{Transition Milk Feeding and Post-Day 1 Supplementation of Colostrum}

The process of "gut closure," in which the neonatal intestine becomes impermeable to macromolecules in the gut, specifically $\operatorname{IgG}$, occurs approximately 24 $\mathrm{h}$ after birth (Lecce and Morgan, 1962; Stott et al., 1979). Despite this, previous research has demonstrated positive effects of feeding colostrum or supplementing colostrum or IgG after the first day of life on calf health and development. For instance, supplementing calves with colostrum replacer to deliver $20 \mathrm{~g}$ of IgG in milk replacer (MR) from birth to $14 \mathrm{~d}$ resulted in lower mortality rates and reduced antibiotic treatments of diarrhea (Geiger et al., 2019). However, no effects on time to diarrhea resolution or mortality rates were observed in a similar study where diarrheic calves were supplemented with $20 \mathrm{~g}$ of IgG in MR daily for $14 \mathrm{~d}$ compared with diarrheic control calves fed a placebo supplement of similar nutritional value (Chung et al., 2019). In addition to feeding a colostrum replacer, supplementing pasteurized colostrum at $0.7 \mathrm{~kg} / \mathrm{d}$ with $4.3 \mathrm{~kg} / \mathrm{d}$ of WM reduced the prevalence of diarrhea and pneumonia (Kargar et al., 2020), and extending colostrum feedings for $14 \mathrm{~d}$ reduced the incidence of diarrhea and antimicrobial treatment (Berge et al., 2009). A short-term study demonstrated that feeding colostrum or a 1:1 colostrum:whole milk mixture (to simulate transition milk feeding) after the initial colostrum meal for the first $3 \mathrm{~d}$ of life increased small intestinal surface area and cell proliferation in certain 
intestinal segments (Pyo et al., 2020) and increased concentrations of plasma glucagon-like peptide-1 (Inabu et al., 2019) compared with calves fed WM. It is possible that enhanced intestinal development in calves provided with extended colostrum feedings or transition milk may be responsible for the aforementioned positive health outcomes in previous studies (Berge et al., 2009; Kargar et al., 2020). However, it is necessary to elucidate whether specific bioactive compounds (as previously mentioned) or the synergistic effects of multiple colostral bioactive molecules are responsible for improving both intestinal development and health status of young calves. Furthermore, current doses and duration of colostrum supplementation after the first day of life are variable and largely based on practical considerations. Determining the ideal supplemental dose and duration for optimizing calf and lifetime performance is required in future studies.

\section{Future Directions}

The relationship between prepartum nutrient intake (emphasized herein as energy intake) and colostrum composition requires further investigation. However, it is important that prepartum diets are designed to first promote a smooth transition to lactation for the dam and second promote calf TPI and overall development through consumption of high-quality colostrum. It is becoming increasingly clear that colostrum serves not only to provide TPI for the neonatal calf, but also to influence its growth and development. Transitioning calves gradually from colostrum to milk and extended supplementation of colostrum in the first weeks of life have beneficial effects on calf health and gastrointestinal development. Results from previous studies (Baumwart et al., 1977; Hiltz and Laarman, 2019; Opgenorth et al., 2020) have demonstrated that future research evaluating the specific effects of FA, including n-3 FA, in colostrum on calf immune function and oxidative stress is of interest. Furthermore, the role of additional bioactive compounds, including OS, miRNA, maternal leukocytes, hormones, and nucleotides, in colostrum and transition milk in neonatal development and immunity need to be tested directly in neonatal calves. These findings will allow the dairy industry to optimize its definition of "high-quality colostrum" and potentially create nonantimicrobial solutions to reduce the current high rates of morbidity and mortality experienced by young calves.

\section{PREWEANING}

Beyond the critical role of colostrum management in terms of health and survival of calves, choices re- lated to the liquid feeding program in the preweaning phase also significantly influence calf development and future performance. Over the past decade, research in calf nutrition has highlighted the importance of feeding adequate levels of milk on preweaning growth and welfare (Soberon et al., 2012; Rosenberger et al., 2017). Although WM may have an optimal composition in relation to calf's requirements, MR provides a more consistent nutrient supply in terms of composition and percentage of solids (Hill et al., 2009). Approximately $35 \%$ of dairy calves in the United States are currently fed exclusively MR, and approximately $25 \%$ are fed a combination of MR and WM (Urie et al., 2018a); thus, calves fed MR represent a large part of the dairy calf population. Commercial MR formulations are highly variable, and recent research has highlighted the differences between conventional MR formulations and WM (Amado et al., 2019; Welboren et al., 2021). These formulations include MR with high lactose (40-50\%; Wilms et al., 2020) or high protein (24-26\% DM; Hill et al., 2008) and MR containing fat content close to that of WM (i.e., $\geq 23 \%$; Amado et al., 2019; Berends et al., 2020).

\section{Energy Requirements in Preweaning Calves}

For young calves between 25 and $50 \mathrm{~kg}$ and fed only WM or MR, net energy maintenance requirements were set at $0.086 \mathrm{Mcal} / \mathrm{kg}^{0.75}$ of live weight daily according to NRC (2001). Thus, a calf weighing $50 \mathrm{~kg}$ should receive $0.78 \mathrm{~kg} / \mathrm{d}$ of DMI $(\sim 5.0-6.5 \mathrm{~L})$ to reach an ADG of $600 \mathrm{~g} / \mathrm{d}$. Yet, over half of US farms provide dairy heifer calves with 4.0 to $5.0 \mathrm{~L}$ of milk/d (10\% of birth BW; USDA, 2016). Compared with current trends in calf nutrition, these volumes are considered to represent a moderate to low plane of nutrition (Rosenberger et al., 2017). Calves provided with milk allowances of $\sim 10 \%$ of birth BW daily display signs of hunger (Thomas et al., 2001; Jensen and Holm, 2003; De Paula Vieira et al., 2008) and have reduced growth (Jasper and Weary, 2002; Khan et al., 2011; Kiezebrink et al., 2015) compared with calves fed larger volumes of milk. Recent research has focused on feeding elevated planes of milk nutrition ( $20 \%$ birth BW; MacPherson et al., 2016; Welboren et al., 2019; Berends et al., 2020) to replacement heifers, because higher preweaning ADG from increased milk allowance is associated with enhanced first-lactation and lifetime productivity (Soberon et al., 2012; Soberon and Van Amburgh, 2013; Gelsinger et al., 2016), as well as improved welfare (De Paula Vieira et al., 2008; Rosenberger et al., 2017). Calves fed ad libitum during the preweaning phase can achieve higher growth (823-1,100 g/d; Berends et al., 2020; Echeverry-Munera et al., 2021) than the upper ADG 
range $(600-800 \mathrm{~g} / \mathrm{d})$ presented in NRC (2001) recommendations, which are in line with those observed in calves reared with their dams (Flower and Weary, 2001). Maintenance energy requirements are influenced by feeding levels (Labussière et al., 2011) and models predicting energy requirements and growth of calves fed high planes of nutrition $(\sim 20 \%$ of BW) remain to be evaluated. Feeding greater volumes of liquid feed benefits calf health and performance, but it is unclear whether current MR formulations are adequate for high feeding rates in preweaning calves as MR presents nutrient imbalances when compared with WM.

\section{Lactose Inclusion in Milk Replacer}

Milk replacers often contain higher levels of lactose $(\sim 45$ vs. $35 \%$ of $\mathrm{DM})$ and lower levels of fat ( $\sim 16$ vs. 30\%; Lee et al., 2009; Moallem et al., 2010; Amado et al., 2019) relative to WM. Prolonged intake of MR containing high levels of lactose was shown to result in impaired glucose homeostasis and insulin sensitivity in heavy veal calves older than 4 mo of age (HostettlerAllen et al., 1994; Hugi et al., 1997). However, in calves 4 wk of age fed MR with either $37 \%$ or $44 \%$ lactose (up to $7.0 \mathrm{~L}$ of $\mathrm{MR} / \mathrm{d} ; 150 \mathrm{~g} / \mathrm{L}$ ), an intravenous glucose challenge showed that insulin sensitivity remained unchanged, and only minimal postprandial differences were detected regarding insulin and glucose dynamics (MacPherson et al., 2016; Stahel et al., 2019). Similarly, insulin sensitivity was unaffected when veal calves were fed MR containing 34 or $60 \%$ lactose for $13 \mathrm{wk}$ at $>10$ L/d (Pantophlet et al., 2016a). Furthermore, replacing one-third of lactose with glucose, fructose, or glycerol did not affect insulin sensitivity compared with calves fed a MR containing $48 \%$ lactose for $55 \mathrm{~d}$ at a rate of 10 L/d (Pantophlet et al., 2016b). However, in the same study, calves fed MR with high lactose or MR with one-third of lactose replaced with glucose suffered from hyperglycemia and glucosuria. Despite the challenges in maintaining glucose homeostasis, these high-lactose and high-glucose MR formulations did not affect growth performance of calves (Pantophlet et al., 2016b; Wilms et al., 2020). However, gradual lactose replacement with glucose in an MR containing $47 \%$ lactose (\% of DM) from 2 to 10 wk of age linearly increased mortality in calves (Wilms et al., 2020).

Beyond possible effects on glucose homeostasis, large amounts of lactose may challenge the gastrointestinal tract of young calves (Hof, 1980; Wilms et al., 2019), as lactose intake can exceed the absorptive capacity. Furthermore, galactose absorption may be reduced in the presence of high glucose concentrations (Hof, 1980). Incomplete digestion of lactose and inefficient galactose absorption increases the carbohydrate load entering the lower intestinal tract. Unabsorbed nutrients and their fermentative products increase gut lumen osmolality, which may impair the ability of young calves to maintain the osmotic gradient for water and nutrient absorption, potentially resulting in osmotic diarrhea (Hof, 1980; Jodal and Lundgren, 1986). Feeding hypertonic MR with osmolality $>400 \mathrm{mOsm} / \mathrm{kg}$ (compared with $\sim 300 \mathrm{mOsm} / \mathrm{kg}$ in WM) can further challenge the absorptive capacity of calves and may compromise gut barrier function (Wilms et al., 2019). According to Hof (1980), daily lactose consumption should not exceed $10 \mathrm{~g}$ of hexose equivalents per $\mathrm{kg}$ of $\mathrm{BW} / \mathrm{d}$. This is equivalent to $6.7 \mathrm{~L}$ of MR ( $45 \%$ lactose, \% DM; $15 \%$ solids) per day for a $45-\mathrm{kg}$ calf.

\section{Fat Inclusion and Fat Composition in Milk Replacer}

Dietary fat from WM provides about $50 \%$ of total dietary energy, as well as essential FA to young animals. Tikofsky et al. (2001), Bartlett et al. (2006), and Hill et al. (2008) have all advocated for low-fat formulations, as higher MR fat inclusion increased tissue fat deposition, an effect that is proposed to impair mammary development (Sejrsen and Purup, 1997). However, although increased mammary gland fat deposition in weaned heifers is thought to be associated with lower milk production (Sejrsen and Purup, 1997), there is no evidence that mammary gland fat deposition in preweaning calves leads to adverse effects on milk production. Adipose tissue is highly metabolic and a potent endocrine organ (Frayn et al., 2003); thus, whether fat deposition is beneficial or detrimental for young animals requires further consideration. The degree of adiposity may critically determine beneficial or detrimental effects. Fat stores are mobilized during infection and may explain the association between nutritional status and mortality in infants (Kuzawa, 1998). Similarly, increased fat intake from liquid feed is associated with decreased mortality in preweaned calves (Urie et al., 2018b). In addition, calves fed MR with high fat (23\% DM; $150 \mathrm{~g} / \mathrm{L})$ ad libitum required less therapeutic interventions from birth until $77 \mathrm{~d}$ of age (Berends et al., 2020), and calves fed MR with high fat $(31 \% \mathrm{DM})$ restricted to 6.0 to $7.0 \mathrm{~L} / \mathrm{d}(150$ $\mathrm{g} / \mathrm{L}$ ) had lower preweaning fecal scores compared with calves fed MR with high lactose inclusion $(>40 \%$ DM; Amado et al., 2019). Feeding higher levels of fat preweaning likely also improves later life performance. Moallem et al. (2010) showed that calves fed WM (29\% fat) ad libitum had an increased milk production compared with calves fed an MR containing only $13 \%$ fat $(12.5 \%$ solids $)$. The authors attributed these effects to paracrine or endocrine factors of fat tissues on mammary parenchyma. 
Beyond the lower fat content, MR differs substantially in fat composition (FA profile) and structure (triglyceride structure and fat globule size and structure) compared with WM (Esselburn et al., 2013; Hageman et al., 2019). Differences in FA composition are linked to the fat sources used in MR, which are primarily vegetable oils (e.g., coconut, palm, and rapeseed; Yohe et al., 2021) in Europe and animal fats (e.g., lard and tallow) in North America (Esselburn et al., 2013). Differences between WM and MR are relevant, as FA profile and triglyceride structure influence fat absorption (Hamilton and Raven, 1972) and gastrointestinal and immune system development in newborn animals (Guilloteau et al., 2004; Hageman et al., 2019). In infant nutrition, the milk fat globule membrane present in fresh breast milk plays a key role in metabolism and developmental processes (Gallier et al., 2015). In contrast, lipid droplets in MR do not contain milk fat globule membranes and are instead coated with casein and milk proteins (Lopez et al., 2015). The effect of fat composition in MR in relation to health and development in calves requires further investigation.

\section{Protein Inclusion, Quality, and Source in Milk Replacer}

The protein content of current MR formulations ranges between 20 and $28 \% \mathrm{DM}$, whereas WM contains 24.5\% DM (Hill et al., 2008; Moallem et al., 2010; USDA, 2011). Increasing the protein content of isocaloric $\mathrm{MR}$ (>protein:energy ratio) increased growth rates and gain-to-feed ratios when fed at 10 to $15 \%$ of $\mathrm{BW}$ daily in Bartlett et al. (2006), and similar performance was reported in Jaeger et al. (2020). Furthermore, the protein gain to $\mathrm{N}$ intake was greater at a higher feeding rate, suggesting that producers could increase efficiency of $\mathrm{N}$ use by providing calves with greater amounts of MR (Bartlett et al., 2006). This is especially important during the first weeks of life, because $\mathrm{N}$ utilization for $\mathrm{N}$ retention is approximately $70 \%$ in calves between 50 and $100 \mathrm{~kg}$ and decreases as BW increases (Gerrits, 2019). As greater growth rates are targeted and achieved by feeding more milk, there is relatively more protein required for deposition of lean tissue. When protein intake is less than required for lean tissue growth, excess dietary energy will be stored as fat. Conversely, when protein intake exceeds requirements for lean tissue growth relative to energy intake, excess protein will be catabolized for energy production, resulting in inefficient use of dietary protein (Bartlett et al., 2006). Therefore, to optimize gain-to-feed ratio when feeding at $\sim 15 \%$ of BW daily, it is recommended to feed an MR (when reconstituted at $12.5 \% \mathrm{DM}$ with water) with approximately 22\% CP (Bartlett et al., 2006). Optimal levels of protein for calves following recent trends to allow for greater allowances of liquid feed $(\sim 20 \%$ of BW) in calf nutrition remains to be evaluated.

Protein source is similarly important because it can affect digestibility, subsequently inducing variations in calf growth performance (Raeth et al., 2016; Morrison et al., 2017). Milk proteins, such as whey protein concentrates, dry skim milk, or sweet whey powder, have greater digestibility ( $94 \%$; Guilloteau et al., 1986; Raeth et al., 2016) than vegetable proteins. Vegetable proteins include wheat and soy proteins and typically have a lower utilization in calves due to their imbalanced AA profile and the presence of antinutritional factors (Branco Pardal et al., 1995; Miqueo et al., 2017). However, a few highly processed sources of vegetable proteins, such as hydrolyzed wheat protein, may still represent suitable alternatives to reduce the dependence on dairy ingredients (Castro et al., 2016; Raeth et al., 2016). Furthermore, whey protein concentrate can be replaced by plasma protein $(25 \%$ of $\mathrm{CP}$ ) or plant peptide powder ( $25 \%$ of CP) without negatively affecting growth performance (Raeth et al., 2016; Morrison et al., 2017); however, more research is required to investigate how these protein and AA sources can profoundly affect growth and health.

\section{Future Directions}

Recent literature shows that milk feeding levels currently applied in the industry do not reflect the volumes that would be voluntarily consumed (Rosenberger et al., 2017; Berends et al., 2020; Echeverry-Munera et al., 2021). Despite positive effects on calf health and welfare, increasing planes of milk nutrition raises the question of whether current MR formulations are optimal (Amado et al., 2019; Echeverry-Munera et al., 2021). Interesting directions for future research in preweaning calf nutrition include the pathways in which MR macronutrient profile and micronutrient composition modulate calf health and development. Furthermore, the relation between fat sources (animal vs. vegetable oils) and fat globule size and structure (with or without fat globule membrane) on metabolism and immune function remain relatively unexplored. Last, the availability of dairy ingredients for MR manufacturing is market dependent, showing the need to explore alternative ingredients.

\section{WEANING}

Understanding the most efficient way to provide liquid feeding programs to calves is important during the preweaning phase, but of equal importance is the introduction of solid feed, which allows for the metabolic 
and physiological transition from a nonruminant to a ruminant. A recent survey of UK dairy farms showed a lack of consensus regarding how best to transition calves from liquid to solid feed, with health and growth emphasized as the greatest concerns during the weaning transition (Palczynski et al., 2020). There is interest in introducing solid feed (i.e., starter/concentrates and forages) early in life to encourage early consumption and subsequent rumen growth and development to ensure a smooth weaning transition. However, regardless of WM or MR feeding level, solid feed consumption is low during the first $3 \mathrm{wk}$ of life (Quigley et al., 2018). After the initial weeks of life, preweaning starter intake and liquid feed intake are inversely correlated, which may negatively affect preweaning growth (Gelsinger et al., 2016; Silva et al., 2019). Specifically, for each 100 $\mathrm{g}$ of MR DMI, starter DMI decreased by $13 \mathrm{~g} / \mathrm{d}$ at 30 d of age and by $\sim 93 \mathrm{~g} / \mathrm{d}$ at $60 \mathrm{~d}$ of age (Silva et al., 2019). Thus, it is thought that feeding a high plane of WM or MR nutrition preweaning causes a decrease in growth rate postweaning, largely due to an inability to consume and digest sufficient quantities of starter for growth (Dennis et al., 2018; Quigley et al., 2018). It is important to note that not all energy and protein sources are going to provide the same amount of energy or required AA for calf and heifer growth. This review focuses only on the key concepts and, as such, will not discuss different energy and protein sources that may be used in calf and heifer diets. Further information can be found in the following reviews: Khan et al. (2016), Heinrichs et al. (2017), Kertz et al. (2017), and Gerrits (2019).

\section{Weaning Strategies}

Previously reviewed studies clearly show that gradual step-down protocols can be implemented to mitigate the negative side effects of weaning from a high plane of WM or MR (Khan et al., 2011, 2016; Meale et al., 2017a). These protocols also efficiently enable calves to maintain elevated growth rates resulting from high planes of milk nutrition from pre- to postweaning (Khan et al., 2007; Silper et al., 2014; Eckert et al., 2015). If higher planes of milk are fed, weaning should be delayed until after 8 wk of age to avoid weaning growth depression (Eckert et al., 2015; Meale et al., 2015, 2017b). In addition to age of weaning, implementation of a step-down protocol is essential, and recommendations generally agree that longer step-down periods are better for calves ( $>10 \mathrm{~d}$ gradual step-down; Sweeney et al., 2010). Furthermore, it is pertinent that the steps are gradual, because abrupt weaning is associated with growth depression (Khan et al., 2007; Sweeney et al., 2010; Steele et al., 2017). With the advancement of automated feeders, it is now possible to step down calves from elevated milk levels by gradually reducing milk allowances over an extended period (Welboren et al., 2019). More importantly, we can also measure solid feed intake and use these measurements to determine the optimal onset of weaning (Benetton et al., 2019). Although these advancements in weaning strategies have been critical to the implementation of sound weaning strategies in the dairy industry, there remains a paucity of information around how the composition of solid feed (concentrate and forage) affects calf growth, health, and development, as well as how solid feeds can be tailored to fit these weaning strategies.

\section{Energy Inclusion in Solid Feed Diets}

The main sources of energy in calf feeds (i.e., liquid or solid) are carbohydrates and fat, with rapidly fermentable carbohydrates providing the majority of carbohydrate ME in solid feed. With respect to NFC (e.g., starch, sugar, and pectin) intake, Quigley et al. $(2019 a, b)$ determined that when calves consume $<15$ $\mathrm{kg}$ of cumulative NFC throughout life, ME intake is overestimated based on NRC (2001) equations, indicating that studies using the NRC (2001) model have likely overestimated ME availability. Quigley et al. (2019a,b) suggested that cumulative NFC intake has a greater relationship with total-tract digestibility of nutrients than calf age, MR intake, or daily nutrient intake. There may be specific situations in which the type or form of starter, or specific ingredients, may appear more appropriate than others. For example, Suárez et al. (2006a,b) demonstrated that a 49.3\% NDF (\% DM) and $10.8 \%$ starch (\% DM) pelleted starter, compared with a $9.4 \%$ NDF (\% DM) and $59.3 \%$ starch (\% DM) pelleted starter, decreased epithelial thickness in the ventral rumen, but improved starter DMI, ADG, total rumen VFA concentration, and rumen weights in 12 -wk-old veal calves fed starter at a maximum of 750 $\mathrm{g} / \mathrm{d}$. No differences in blood BHB concentrations at 12 wk were observed between the treatment groups, suggesting that age, as opposed to solid feed intake, is a critical factor in determining the onset of functional rumen epithelium development (as corroborated by Lane et al. (2000, 2002) and Yohe et al. (2019)). Metabolizable energy intake from solid feed (mainly as NFC in starter/concentrate) promotes overall growth and adequate rumen development, yet related health issues, such as ruminal or hindgut acidosis (Gressley et al., 2011; Gelsinger et al., 2020), are thought to compromise calf growth and health during weaning (Steele et al., 2017; Meale et al., 2017a). Gelsinger et al. (2020) reported that calves fed only pelleted calf starter (CS; $42.7 \%$ starch, $15.1 \% \mathrm{NDF}, 57.8 \% \mathrm{NFC}$ ) or texturized 
CS (35.3\% starch, $25.3 \% \mathrm{NDF}, 48.1 \% \mathrm{NFC})$ for $17 \mathrm{wk}$ both experience some degree of ruminal acidosis but that calves fed pelleted CS experience reduced feed intake and BW gain and a higher degree of ruminal tissue damage. However, it is important to note that low rumen $\mathrm{pH}$ as a result of solid feed intake is common in calves that do not experience adverse health events as well (Li et al., 2012; Laarman et al., 2012; van Niekerk et al., 2021), and thus, requires further investigation. In contrast to using rapidly fermentable carbohydrates to increase energy in starters, increasing rumen inert fat content in starter diets from $3.3 \%$ fat $(6.17 \pm 0.10$ Mcal of ME intake/d on DM basis) to $6.8 \%$ fat (7.06 \pm $0.10 \mathrm{Mcal}$ of ME intake/d on DM basis) using extrusion increased BW gain and starter intake (Berends et al., 2018). Diets were isonitrogenous (17.1\% CP, \% DM) in this study, indicating that overall energy supply is essential during weaning to support ADG as opposed to starter intake. Yet, body composition was not measured and, thus, it is unclear if BW gain was due lean or adipogenic tissue deposition.

\section{Protein Inclusion in Solid Feed Diets}

Similar to energy, dietary protein varies depending on the source and inclusion amount fed to calves. The NRC (2001) recommends that starters containing $18 \%$ $\mathrm{CP}(\% \mathrm{DM})$ are adequate to promote maintenance and growth in calves. No differences in ADG (0.74 vs. 0.80 $\pm 0.06 \mathrm{~kg} / \mathrm{d}$; Stamey et al., 2012) were observed over a 10 -wk period when feeding starter that differed in CP $(19.6$ or $25.5 \% \mathrm{CP}, \% \mathrm{DM})$, but not ME content $(\sim 3.2 \mathrm{Mcal} / \mathrm{kg}$ of $\mathrm{DM})$, suggesting that even a large increase in CP:ME intake ( 64 vs. $75 \mathrm{~g}$ of $\mathrm{CP} / \mathrm{Mcal}$ of ME based on average of wk 5 and 7 for low and high $\mathrm{CP}$, respectively) does not always confer growth benefits. However, it is important to note that a high CP MR (30.8\% CP, \% DM; 4.72 Mcal of ME $/ \mathrm{kg}$ of $\mathrm{DM})$ was fed in this study and may have influenced results. Yet, feeding a low CP MR $(20 \% \mathrm{CP})$ resulted in no differences in ADG $(0.63-0.67 \pm 0.02 \mathrm{~kg} / \mathrm{d})$ in calves fed starter differing in CP:ME (67.4-71.4 g CP/ Mcal of ME; Jaeger et al., 2020). Collectively, these results suggest there is little advantage to feeding starter containing more than 18\% CP (\% DM) to increase growth during weaning. It is important to note that many of these studies only consider CP supply, and not AA supply, which has been rarely studied in solid feeds (Quigley et al., 1985; Molano et al., 2020) but has great potential to optimize nutrient supply after weaning.

Utilizing protein for tissue and overall growth is valuable if used efficiently. Calves are largely inefficient at retaining N (Berends et al., 2014, 2015a), as N retention decreases by increasing protein intake via solid feed in unweaned veal calves from 11 to $27 \mathrm{wk}$ (i.e., $19 \%$ of improved $\mathrm{N}$ retention in the rumen due to urea recycling back to the rumen). Adequate rumen $\mathrm{N}$ is important for microbial growth. When $\mathrm{CP}$ consumption is only $93 \mathrm{~g} / \mathrm{kg}$ of DM, compensatory urea recycling is not sufficient to support microbial growth and, thus, results in insufficient outflow of microbial $\mathrm{CP}$ from the rumen (Berends et al., 2015a). This suggests that a calf needs to consume a $21 \% \mathrm{CP}(\% \mathrm{DM})$ starter at a rate of $\sim 443 \mathrm{~g}$ of $\mathrm{DM} / \mathrm{d}$, assuming a $4.1 \% / \mathrm{h}$ rumen passage rate (Berends et al., 2015b), to maintain adequate $\mathrm{N}$ balance in the rumen to support microbial fermentation. Yet, forage consumption also contributes to dietary $\mathrm{CP}$ intake, with alfalfa hay and barley straw containing $\sim 16.6 \%$ and $\sim 4.2 \% \mathrm{CP}(\% \mathrm{DM})$, respectively (Castells et al., 2012). Considering the observation of approximately 13\% DMI (pre- to postweaning of starter and forage) of alfalfa hay by Castells et al. (2013) and the $93 \mathrm{~g}$ of $\mathrm{CP} / \mathrm{kg}$ of DMI from solid feed (50\% concentrates, $25 \%$ corn silage, and $25 \%$ straw on a DM basis) noted by Berends et al. (2015a) required to support rumen microbial growth, alfalfa hay would need to provide approximately $12 \mathrm{~g}$ of $\mathrm{CP} / \mathrm{kg}$ of DMI (Castells et al., 2012). If microbial protein synthesis is not optimized during weaning, the starter/concentrate/ forage becomes the primary source of protein and AA in the rumen. The factors that contribute to microbial protein synthesis have been well researched in mature dairy cows (Clark et al., 1992) but have been rarely studied in starter feeds for calves (Quigley et al., 1985). Even though it can be technically challenging, it is important to estimate microbial protein synthesis in future experiments and develop a deeper understanding of how it changes during weaning to supply the optimal level of high-quality protein to the calf.

\section{Future Directions}

Numerous advancements over the past decade have improved our approach to weaning age and step-down strategies depending on the milk feeding level. However, future research should aim to refine the specific combination of WM and MR and specific starter/ concentrate/forage ratios to optimize calf growth and development. Understanding total DMI, ME, protein, and AA intake is a critical first step, but determining how to appropriately balance the amount of ME and protein supplied in both liquid and solid feed based on plane of WM/MR, and further acknowledging their interactions, will further improve efficiency during the preweaning and weaning periods. Improving equations in our nutritional models to predict solid feed carbohydrate digestion and microbial protein synthesis at different stages of weaning would also be highly valu- 
able. With automated feeding of liquid and solid feed, tailoring individualized weaning strategies to maintain nutrient intake and growth during weaning is now possible but, unfortunately, rarely implemented.

\section{PREPUBERTAL AND POSTPUBERTAL PHASES}

After fully transitioning to solid feed, there are many different strategies that can be employed to ensure proper development during the next crucial stages of life (i.e., puberty, pregnancy, calving). The established guidelines for heifers in our industry is to target first calving between 22 and 24 mo at $0.82 \times$ mature BW (Van Amburgh et al., 2019); however, recent data suggests that a target of 0.73 to $0.77 \times$ mature $\mathrm{BW}$ increases milk production in first lactation without compromising long-term production (Han et al., 2021). Certainly, heifer rearing targets and requirements are not well understood during the prepubertal and postpubertal phases and may be influenced by nutrition earlier in life. Several recent reviews (Heinrichs et al., 2017; Van Amburgh et al., 2019; Erickson et al., 2020) have compiled management strategies proposed to optimize heifer calf nutrition from prepuberty to first calving to reduce rearing costs, optimize age at first calving, and improve milk production. Although the developmental plasticity at this stage of life is lowest (Figure 1), some examples have illustrated how altering nutrition programs can affect future productivity. For example, Ford and Park (2001) showed that Holstein heifers receiving multiple nutrient restrictions during the prepubertal, pubertal, and gestation periods, followed by realimentation to normal diets, increased milk production in first lactation. Few replacement heifer studies have investigated growth and development past weaning, which is surprising given that the prepubertal period after weaning represents the highest feed efficiency for growth (Bach and Ahedo, 2008). Furthermore, several key areas still need to be addressed, including when to transition calves from high-energy and protein-concentrate diets to lower energy and highprotein forage diets in the prepubertal period, as well as determining the optimal energy and protein provisions to maximize growth and development before and after puberty.

\section{Energy Provision}

Transitioning prepubertal heifer calves after weaning from high-concentrate diets rich in rapidly fermentable carbohydrates to forage-based diets is a traditional strategy to control energy intake and avoid excessive adipogenesis. It has been suggested that high-concentrate and energy diets during the prepubertal stage of life can cause an accumulation of adipose tissue in the developing mammary gland and may ultimately lead to reduced milk yield later in life (Sejrsen and Purup, 1997; Van Amburgh et al., 2019). For this reason, the inclusion of high amounts of concentrate in the prepubertal diet has been approached cautiously. However, excessive forage provision after weaning limits dry feed intake and growth due to an apparent limit of NDF intake as a percentage of BW (defined as $1 \%$ of BW by Hoffman et al., 2008 and Mitchell and Heinrichs, 2020). Reducing forage particle size may mitigate reductions in total DMI, but most importantly forage provision at weaning should be controlled to increase overall dietary intake. Forage provision can be affected by age, nutrient composition, and physical form of both concentrate and forage and is important for rumen buffering and physical abrasion of the rumen wall, even when fed in low amounts (5\% of diet; Suarez-Mena et al., 2016). Calves fed high-concentrate diets $(85 \%)$ for the months immediately following weaning can achieve high ADG (>1.5 kg/d; Groen et al., 2015; Rosadiuk et al., 2021). However, the optimal duration of high-concentrate feeding and how this may affect fat deposition, feed efficiency, and future milk production is still unknown.

The most important variable that can be manipulated in replacement heifers during the prepubertal-to-pregnancy stage is growth rate. Growth rate can influence breeding age, age at first calving, lifetime productivity, and feed costs (Heinrichs et al., 2017; Van Amburgh et al., 2019; Erickson et al., 2020) and will be the main focus of this section. Several studies have investigated the effect of prepubertal ADG on milk production. Zanton and Heinrichs (2005) and Heinrichs et al. (2017) stated that $\sim 0.8 \mathrm{~kg} / \mathrm{d}$ is the optimal prepubertal growth rate. However, to our knowledge, the studies reviewed by Heinrichs et al. (2017) fed low to moderate planes of nutrition preweaning, which may have influenced the postweaning growth rates of prepubertal heifers. For instance, calves fed a high-protein MR $[30.6 \% \mathrm{CP}$ and $16.1 \%$ fat $(\% \mathrm{DM})$ fed at $2.1 \%$ of $\mathrm{BW}$ ] and starter $(24.3 \% \mathrm{CP} ; \% \mathrm{DM})$ diet to achieve ADG of $0.68 \mathrm{~kg} / \mathrm{d}$ achieved puberty earlier $(270 \pm 5.8 \mathrm{~d}$ and $287 \pm 5.5$ $\mathrm{kg}$ of BW) than calves fed a conventional MR $[21.5 \%$ $\mathrm{CP}$ and $21.5 \%$ fat (\% DM) fed at $1.2 \%$ of $\mathrm{BW}$ ] and starter $(19.9 \% \mathrm{CP} ; \% \mathrm{DM})$ to achieve $0.45 \mathrm{~kg} / \mathrm{d} \mathrm{ADG}$, in which puberty was not attained until BW was $>300$ $\mathrm{kg}$ (Davis Rincker et al., 2011). Yet, this difference only led to a tendency for fewer days to conception and did not affect days to parturition or lactation (i.e., average milk through 150 DIM, projected 305-d milk, or milk component yields). Thus, plane of milk nutrition may not have a large effect on the primary outcomes associated with the efficiency and profitability of dairy operations (i.e., age at first calving). However, that study is 
one of the first to investigate the effect of preweaning nutrition on puberty onset and parameters directly associated with the profitability of dairy operations and thus requires additional work. Further, there are limited studies with sufficient replication following calves from preweaning to pregnancy, with a lack of evidence showcasing different protein and energy intakes during both phases.

A recent study observed that increased planes of nutrition during both the pre- and postweaning periods resulted in greater ADG and indicators of growth and development in heifer calves up to 25 wk of age (Rosadiuk et al., 2021). The increased preweaning planes of nutrition had minimal influence on growth performance postweaning, regardless of the improved indicators of growth and development in the preweaning stage. As reported in companion manuscripts (Bruinjé et al., 2019, 2020), increased pre- and postweaning planes of nutrition resulted in advanced reproductive development. The increased preweaning plane of nutrition resulted in enhanced LH pulses at wk 15, increased circulating leptin concentrations (Bruinjé et al., 2019), and a greater number of class 2 ovarian follicles (Bruinjé et al., 2020) during the prepubertal phase. The increased planes of nutrition postweaning resulted in increased endometrial thickness, follicular size, number of class 3 follicles in the prepubertal phase (Bruinjé et al., 2020), greater likelihood of achieving puberty by 30 wk of age (Bruinjé et al., 2019), and increased antral follicle population in the postpubertal phase. Both the high pre- and postweaning nutritional planes had elevated energy and protein content; thus, the respective effects of plane of energy or protein on growth and reproductive development cannot be distinguished. Further research is warranted to investigate how protein or energy content during the preweaning, postweaning, and prepubertal stages affect the onset of puberty and subsequent reproductive performance in heifer calves. Furthermore, a better understanding of early-life factors influencing the ideal body size, composition and age that heifers should enter the breeding program for optimal performance is crucial. For instance, if too much forage is added to the diet in the months postweaning, it may decrease ADG (by $0.5 \mathrm{~kg} / \mathrm{d}$; Groen et al., 2015) and could ultimately delay age at puberty (Bruinjé et al., 2020). This potential delay in puberty onset may increase nonproductive days on feed, ultimately affecting replacement heifer rearing cost. Therefore, maximizing growth rates during the prepubertal phase when feed efficiency is elevated could be an effective means of maximizing growth before the onset of puberty, but the long-term consequences on growth, development, and milk production need to be investigated.
Fibrous feedstuffs are often incorporated into the diet of prepubertal heifers as a means of manipulating intake and ADG (Akins, 2016; Erickson et al., 2020). One strategy to aid in the prevention of overconditioning heifers from preweaning through pregnancy is to include a higher amount of low-quality forage (e.g., grass hay, wheat straw, or other forage sources) in the diet (Erickson et al., 2020). This has proven successful in achieving desirable ADG in weaned heifers $(0.92$ $\pm 0.04 \mathrm{~kg} / \mathrm{d}$ of gain) limit-fed a TMR with grass hay and starter (Mitchell and Heinrichs, 2020), as well as pregnant heifers $(0.96$ and $1.04 \pm 0.07 \mathrm{~kg} / \mathrm{d}$ of gain $)$ fed a TMR ad libitum with either alfalfa haylage or corn silage and $32.1 \%$ alfalfa stemlage or $31.3 \%$ alfalfa or corn silage and wheat straw (Su et al., 2017). Hoffman et al. (2008) demonstrated maximum NDF intake at $1 \%$ BW from approximately 4 mo of age to first calving in Holstein and Holstein $\times$ Jersey crossbred heifers. Mitchell and Heinrichs (2020) found that 4-mo-old Holstein heifers consumed NDF at $0.89 \%$ of $\mathrm{BW}$, whereas pregnant heifers (starting BW: $487 \pm 0.8 \mathrm{~kg}$; final BW: $543 \pm 4.1 \mathrm{~kg}$ ) consumed NDF at 0.86 to $0.91 \%$ of BW when fed wheat straw and alfalfa stemlage, respectively (Su et al., 2017). Further, the proportion of undigested NDF is higher in straw than in other forages (Kahyani et al., 2019) and has a negative effect on DMI (Mertens, 2016). A recent study investigated forage provision after weaning at 6 wk until 16 wk of age and noted depressed feed intake and growth when forage inclusion is $>10 \%$ (Mitchell and Heinrichs, 2020). Thus, it is important to consider NDF, and perhaps undigested NDF, in the future when formulating heifer diets to achieve optimal digestibility and growth.

\section{Protein Requirements}

Similar to weaning, the amount of protein fed to calves during the prepubertal and pubertal periods varies in the dairy industry. Gabler and Heinrichs (2003) assessed different CP:ME ratios fed to 4-mo-old heifers utilizing the same amount of forage (corn silage and grass hay), but differing the levels of concentrate ingredients in the diet to increase the CP:ME of the diet from $48.3 \mathrm{~g}$ of $\mathrm{CP} / \mathrm{Mcal}$ of $\mathrm{ME}$ to $59.1,67.5$, and $76.5 \mathrm{~g}$ of $\mathrm{CP} / \mathrm{Mcal}$ of ME. The amounts offered were adjusted weekly to allow for $0.8 \mathrm{~kg} / \mathrm{d}$ ADG for all treatments. The study found a linear improvement in feed efficiency ( $\mathrm{kg}$ of feed intake/ $\mathrm{kg}$ of BW gain) with increasing CP:ME intake. These results suggest that feeding adequate $\mathrm{CP}$ relative to $\mathrm{ME}$ is important for heifers postweaning. Furthermore, this research corroborated previous results demonstrating that a lower NSC:RDP allowed for more efficient protein use for 
growth in calves 3 to 5 mo of age (g/g NSC/RDP for CP:ME ratios were 48:4, 59:3, 68:3, and 77:2; Casper et al., 1994). Yet, the optimal timeframe for reducing NSC intake relative to forage intake remains an important question. Gabler and Heinrichs (2003) and Casper et al. (1994) showed that these changes can be made as early as 3 to 5 mo of age, as long as adequate $\mathrm{CP}$ is supplied. This is supported by Mitchell et al. (2020), where calves $\sim 3$ mo of age offered starter and grass hay ad libitum as separate components reached a plateau in forage consumption (around $0.28 \mathrm{~kg} / \mathrm{d}$, which was $8 \%$ of total DMI), whereas starter intake continued to increase throughout the 14-wk study. This unrestricted starter intake for extended periods likely increased microbial protein supply to support growth rates higher than the commonly recommended ADG of $0.80 \mathrm{~kg} / \mathrm{d}$ to achieve maximal first-lactation milk yield (Zanton and Heinrichs, 2005). More research is required to understand how to maximize microbial protein synthesis during the transition from high-concentrate to high-forage diets to supply prepubertal calves with the protein and AA needed to support growth and development.

\section{Future Directions}

The main goal of the prepubertal and pubertal periods is to achieve appropriate weight gain to reach age at first calving as early as $22 \mathrm{mo}$, while balancing feed input and feed efficiency (Akins, 2016; Heinrichs et al., 2017). As noted in the review by Erickson et al. $(2020)$, this may be achieved through precision feeding, but further evidence showcasing how to effectively implement these strategies is needed. Recent work suggested that a transition from a high-concentrate diet to a high-forage diet should not occur in the initial months following weaning (Rosadiuk et al., 2021). However, research uncovering the optimal time to transition weaned calves to a high-forage diet is lacking. One major consideration is the high ADG and feed efficiencies reported during the prepubertal period, which may more effectively maximize calf $\mathrm{BW}$ than the milk phase of nutrition. Furthermore, the level of protein to include with a high-NDF forage to prevent nutrient waste, promote lean tissue gain, as well as support protein requirements during pregnancy, remains a major knowledge gap that requires attention.

\section{SUMMARY}

There has been great momentum and global interest in the field of calf research, especially around the potential to developmentally program calves in early life to increase productivity and health. However, several knowledge gaps remain related to nutritional manage- ment in each developmental phase (Figure 1) that significantly limit this potential. Expanding our understanding of energy and protein dietary requirements and composition will ultimately improve calf growth and development. Therefore, there is a strong need to integrate this dietary knowledge with health research to mitigate incidences of disease and disorders in calves.

The momentum in calf research has resulted in a vast number of recently published articles. Despite this increase in publications, incomplete reporting in primary studies is unfortunately common in calf and heifer research, making it challenging to construct systematic reviews and meta-analyses (Winder et al., 2018). The dairy science community, including authors, reviewers, and editors, should follow reporting guidelines developed through expert consensus to improve reporting outcomes from livestock trials (Sargeant et al., 2010; Winder et al., 2019). Improved reporting will ultimately lead to a better understanding of the efficacy of nutritional strategies at each stage of life, thereby increasing the value of calf research. Another key experimental point that requires consideration in calf research is the long-term consequence of the imposed dietary treatments on lifetime events. A comprehensive understanding of how nutrition affects developmental programming is only possible if we characterize the effects of early-life treatments, along with follow-up measurements throughout all stages of life, including first lactation. These experiments are challenging because of biological replication constraints in research facilities and the lack of infrastructure to support studies characterizing lifelong events. Nevertheless, strategies to overcome these challenges need to be developed to generate critical knowledge pertaining to the long-term effects of nutritional strategies.

In closing, we have highlighted nutritional aspects, ingredients and composition, and feeding and management strategies that influence fetal and calf development and growth (summarized in Figure 1). It is clear that there is great momentum toward and interest in understanding these effects to improve heifer calf production, efficiency, health, and welfare. However, each life stage requires different nutritional strategies that may or may not have carryover effects or lead to different long-term outcomes, or both. Therefore, it is important to continue pursuing research investigating optimal nutritional strategies to improve calf performance and health without compromising cost efficiency.

\section{ACKNOWLEDGMENTS}

The authors thank Alberta Agriculture and Forestry (Edmonton, AB, Canada); Alberta Milk (Edmonton, AB, Canada); Bayer Animal Health (Mississauga, 
ON, Canada); BC Dairy Association (Burnaby, BC, Canada); Dairy Farmers of Manitoba (Winnipeg, MB, Canada); Lallemand Animal Nutrition (Montreal, QB, Canada); the Natural Sciences and Engineering Research Council of Canada (Ottawa, ON, Canada); Ontario Ministry of Agriculture, Food and Rural Affairs (OMAFRA; Guelph, ON, Canada); Pancosma (Geneva, Switzerland); Trouw Nutrition (Guelph, ON, Canada); The Saskatoon Colostrum Co. Ltd. (Saskatoon, SK, Canada); SaskMilk (Regina, SK, Canada); and Westgen (Abbotsford, BC, Canada) for their funding support. Furthermore, the authors appreciate the suggestions offered by Tana Dennis (Provimi) and David Renaud (University of Guelph). The authors have not stated any conflicts of interest.

\section{REFERENCES}

Abuelo, A. 2020. Symposium review: Late-gestation maternal factors affecting the health and development of dairy calves. J. Dairy Sci. 103:3882-3893. https://doi.org/10.3168/jds.2019-17278.

Akins, M. S. 2016. Dairy heifer development and nutrition management. Vet. Clin. North Am. Food Anim. Pract. 32:303-317. https: //doi.org/10.1016/j.cvfa.2016.01.004.

Aldridge, B. M., S. M. McGuirk, and D. P. Lunn. 1998. Effect of colostral ingestion on immunoglobulin- positive cells in calves. Vet. Immunol. Immunopathol. 62:51-64. https://doi.org/10.1016/S0165 -2427(97)00158-X.

Alharthi, A. S., F. Batistel, M. K. Abdelmegeid, G. Lascano, C. Parys, A. Helmbrecht, E. Trevisi, and J. J. Loor. 2018. Maternal supply of methionine during late-pregnancy enhances rate of Holstein calf development in utero and postnatal growth to a greater extent than colostrum source. J. Anim. Sci. Biotechnol. 9:83-95. https:// doi.org/10.1186/s40104-018-0298-1.

Alharthi, A. S., D. N. Coleman, Y. Liang, F. Batistel, A. A. Elolimy, R. C. Yambao, E. Abdel-Hamied, Y.-X. Pan, C. Parys, I. A. Alhidary, M. M. Abdelrahman, and J. J. Loor. 2019. Hepatic 1-carbon metabolism enzyme activity, intermediate metabolites, and growth in neonatal dairy calves are altered by maternal supply of methionine during late pregnancy. J. Dairy Sci. 102:10291-10303. https:/ /doi.org/10.3168/jds.2019-16562.

Amado, L., H. Berends, L. N. Leal, J. Wilms, H. Van Laar, W. J. J. Gerrits, and J. Martín-Tereso. 2019. Effect of energy source in calf milk replacer on performance, digestibility, and gut permeability in rearing calves. J. Dairy Sci. 102:3994-4001. https://doi.org/10 $.3168 /$ jds.2018-15847.

Bach, A., and J. Ahedo. 2008. Record keeping and economics of dairy heifers. Vet. Clin. North Am. Food Anim. Pract. 24:117-138. https://doi.org/10.1016/j.cvfa.2007.10.001.

Ballou, M. A. 2012. Immune responses of Holstein and Jersey calves during the preweaning and immediate postweaned periods when fed varying planes of milk replacer. J. Dairy Sci. 95:7319-7330. https://doi.org/10.3168/jds.2012-5970.

Bartlett, K. S., F. K. McKeith, M. J. VandeHaar, G. E. Dahl, and J. K. Drackley. 2006. Growth and body composition of dairy calves fed milk replacers containing different amounts of protein at two feeding rates. J. Anim. Sci. 84:1454-1467. https://doi.org/10 $.2527 / 2006.8461454 \mathrm{x}$.

Bartol, F. F., A. A. Wiley, D. J. Miller, A. J. Silva, K. E. Roberts, M. L. P. Davolt, J. C. Chen, A.-L. Frankshun, M. E. Camp, K. M. Rahman, J. L. Vallet, and C. A. Bagnell. 2013. Lactation biology symposium: Lactocrine signaling and developmental programming. J. Anim. Sci. 91:696-705. https://doi.org/10.2527/jas.2012-5764.

Batistel, F., A. S. Alharthi, R. R. C. Yambao, A. A. Elolimy, Y.-X. Pan, C. Parys, and J. J. Loor. 2019. Methionine supply during late-gestation triggers offspring sex-specific divergent changes in metabolic and epigenetic signatures in bovine placenta. J. Nutr. 149:6-17. https://doi.org/10.1093/jn/nxy240.

Batistel, F., A. S. M. Alharthi, L. Wang, C. Parys, Y.-X. Pan, F. C. Cardoso, and J. J. Loor. 2018. Placentome nutrient transporters and mammalian target of rapamycin signaling proteins are altered by the methionine supply during late gestation in dairy cows and are associated with newborn birth weight. J. Nutr. 147:1640-1647. https://doi.org/10.3945/jn.117.251876.

Batistel, F., J. M. Arroyo, A. Bellingeri, L. Wang, B. Saremi, C. Parys, E. Trevisi, F. C. Cardoso, and J. J. Loor. 2017. Ethyl-cellulose rumen-protected methionine enhances performance during the periparturient period and early lactation in Holstein dairy cows. J. Dairy Sci. 100:7455-7467. https://doi.org/10.3168/jds.2017-12689.

Bauman, D. E., and W. B. Currie. 1980. Partitioning of nutrients during pregnancy and lactation: A review of mechanisms involving homeostasis and homeorhesis. J. Dairy Sci. 63:1514-1529. https:// doi.org/10.3168/jds.S0022-0302(80)83111-0.

Baumrucker, C. R., and R. M. Bruckmaier. 2014. Colostrogenesis: IgG1 transcytosis mechanisms. J. Mammary Gland Biol. Neoplasia 19:103-117. https://doi.org/10.1007/s10911-013-9313-5.

Baumwart, A. L., L. J. Bush, M. Mungle, and L. D. Corley. 1977. Effect of potassium isobutyrate on absorption of immunoglobulins from colostrum by calves. J. Dairy Sci. 60:759-762. https://doi .org/10.3168/jds.S0022-0302(77)83931-3.

Bell, A. W. 1995. Regulation of organic nutrient metabolism during transition from late pregnancy to early lactation. J. Anim. Sci. 73:2804-2819. https://doi.org/10.2527/1995.7392804x.

Bell, A. W., W. S. Burhans, and T. R. Overton. 2000. Protein nutrition in late pregnancy, maternal protein reserves and lactation performance in dairy cows. Proc. Nutr. Soc. 59:119-126. https:// doi.org/10.1017/S0029665100000148.

Bell, A. W., R. Slepetis, and R. A. Ehrhardt. 1995. Growth and accretion of energy and protein in the gravid uterus during late pregnancy in Holstein cows. J. Dairy Sci. 78:1954-1961. https://doi .org/10.3168/jds.S0022-0302(95)76821-7.

Benetton, J. B., H. W. Neave, J. Costa, M. von Keyserlingk, and D. M. Weary. 2019. Automatic weaning based on individual solid feed intake: Effects on behavior and performance of dairy calves. J. Dairy Sci. 102:5475-5491. https://doi.org/10.3168/jds.2018-15830.

Benmoussa, A., C. H. Lee, B. Laffont, P. Savard, J. Laugier, E. Boilard, C. Gilbert, I. Fliss, and P. Provost. 2016. Commercial dairy cow milk microRNAs resist digestion under simulated gastrointestinal tract conditions. J. Nutr. 146:2206-2215. https://doi.org/10 $.3945 /$ jn.116.237651.

Berends, H., J. J. van den Borne, N. Stockhofe-Zurwieden, M. S. Gilbert, T. Zandstra, W. F. Pellikaan, C. G. van Reenen, E. A. Bokkers, and W. J. Gerrits. 2015b. Effects of solid feed level and roughage-to-concentrate ratio on ruminal drinking and passage kinetics of milk replacer, concentrates, and roughage in veal calves. J. Dairy Sci. 98:5621-5629. https://doi.org/10.3168/jds.2015-9367.

Berends, H., J. J. G. C. van den Borne, B. A. Røjen, W. H. Hendriks, and W. J. J. Gerrits. 2015a. Effect of protein provision via milk replacer or solid feed on protein metabolism in veal calves. J. Dairy Sci. 98:1119-1126. https://doi.org/10.3168/jds.2014-8375.

Berends, H., J. J. G. C. van den Borne, B. A. Røjen, J. van Baal, and W. J. J. Gerrits. 2014. Urea recycling contributes to nitrogen retention in calves fed milk replacer and low-protein solid feed. J. Nutr. 144:1043-1049. https://doi.org/10.3945/jn.114.191353.

Berends, H., H. van Laar, L. N. Leal, W. J. J. Gerrits, and J. MartínTereso. 2020. Effects of exchanging lactose for fat in milk replacer on ad libitum feed intake and growth performance in dairy calves. J. Dairy Sci. 103:4275-4287. https://doi.org/10.3168/jds.2019 -17382 .

Berends, H., M. Vidal, M. Terré, L. N. Leal, J. Martín-Tereso, and A. Bach. 2018. Effects of fat inclusion in starter feeds for dairy calves by mixing increasing levels of a high-fat extruded pellet with a conventional highly fermentable pellet. J. Dairy Sci. 101:1096210972. https://doi.org/10.3168/jds.2018-15116.

Berge, A. C. B., T. E. Besser, D. A. Moore, and W. M. Sischo. 2009. Evaluation of the effects of oral colostrum supplementation during the first fourteen days on the health and performance of pre- 
weaned calves. J. Dairy Sci. 92:286-295. https://doi.org/10.3168/ jds.2008-1433.

Berry, D. P., P. Lonergan, S. T. Butler, A. R. Cromie, T. Fair, F. Mossa, and A. C. O. Evans. 2008. Negative influence of high maternal milk production before and after conception on offspring survival and milk production in dairy cattle. J. Dairy Sci. 91:329-337. https://doi.org/10.3168/jds.2007-0438.

Blum, J. W., and H. Hammon. 2000. Colostrum effects on the gastrointestinal tract, and on nutritional, endocrine and metabolic parameters in neonatal calves. Livest. Prod. Sci. 66:151-159. https: //doi.org/10.1016/S0301-6226(00)00222-0.

Branco-Pardal, P., J. P. Lallès, M. Formal, P. Guilloteau, and R. Toullec. 1995. Digestion of wheat gluten and potato protein by the preruminant calf: digestibility, amino acid composition and immunoreactive proteins in ileal digesta. Reprod. Nutr. Dev. 35:639-654. https://doi.org/10.1051/rnd:19950604.

Bruinjé, T. C., J. P. Rosadiuk, F. Moslemipur, J. E. Carrelli, M. A. Steele, and D. J. Ambrose. 2019. Carryover effects of pre-and postweaning planes of nutrition on reproductive tract development and estrous cycle characteristics in Holstein heifers. J. Dairy Sci. 102:10514-10529. https://doi.org/10.3168/jds.2019-16249.

Bruinjé, T. C., J. P. Rosadiuk, F. Moslemipur, H. Sauerwein, M. A. Steele, and D. J. Ambrose. 2020. Differing planes of pre- and postweaning phase nutrition in Holstein heifers: II. Effects on circulating leptin, luteinizing hormone, and age at puberty. J. Dairy Sci. 104. https://doi.org/10.3168/jds.2020-18810.

Buczinski, S., E. Gicquel, G. Fecteau, Y. Takwoingi, M. Chigerwe, and J. Vandeweerd. 2018. Systematic review and meta-analysis of diagnostic accuracy of serum refractometry and Brix refractometry for the diagnosis of inadequate transfer of passive immunity in calves. J. Vet. Intern. Med. 32:474-483. https://doi.org/10.1111/ jvim.14893.

Carvalho, M. R., C. Aboujaoude, F. Peñagaricano, J. E. P. Santos, T. J. DeVries, B. W. McBride, and E. S. Ribeiro. 2020. Associations between maternal characteristics and health, survival, and performance of dairy heifers from birth through first lactation. J. Dairy Sci. 103:823-839. https://doi.org/10.3168/jds.2019-17083.

Casper, D. P., D. J. Schingoethe, M. J. Brouk, and H. A. Maiga. 1994. Nonstructural carbohydrates and undegradable protein sources in the diet: Growth responses of dairy heifers. J. Dairy Sci. 77:25952604. https://doi.org/10.3168/jds.S0022-0302(94)77200-3.

Castells, L., A. Bach, G. Araujo, C. Montoro, and M. Terré. 2012. Effect of different forage sources on performance and feeding behavior of Holstein calves. J. Dairy Sci. 95:286-293. https://doi.org/10 $.3168 /$ jds.2011-4405.

Castells, L., A. Bach, A. Aris, and M. Terré. 2013. Effects of forage provision to young calves on rumen fermentation and development of the gastrointestinal tract. J. Dairy Sci. 96:5226-5236. https:// doi.org/10.3168/jds.2012-6419.

Castro, J. J., G. H. Hwang, A. Saito, D. A. Vermeire, and J. K. Drackley. 2016. Assessment of the effect of methionine supplementation and inclusion of hydrolyzed wheat protein in milk proteinbased milk replacers on the performance of intensively fed Holstein calves. J. Dairy Sci. 99:6324-6333. https://doi.org/10.3168/ jds.2015-10639.

Chen, X., C. Gao, H. Li, L. Huang, Q. Sun, Y. Dong, C. Tian, S. Gao, H. Dong, D. Guan, X. Hu, Z. Shujian, L. Li, L. Zhu, Q. Yan, J. Zhang, K. Zen, and C. Y. Zhang. 2010. Identification and characterization of microRNAs in raw milk during different periods of lactation, commercial fluid, and powdered milk products. Cell Res. 20:1128-1137. https://doi.org/10.1038/cr.2010.80.

Chung, J. J., M. C. Rayburn, and M. Chigerwe. 2019. Randomized controlled clinical trial on the effect of oral immunoglobulin supplementation on neonatal dairy calves with diarrhea. J. Vet. Intern. Med. 33:1807-1813. https://doi.org/10.1111/jvim.15538.

Clark, J. H., T. H. Klusmeyer, and M. R. Cameron. 1992. Microbial protein synthesis and flows of nitrogen fractions to the duodenum of dairy cows. J. Dairy Sci. 75:2304-2323. https://doi.org/10 .3168/jds.S0022-0302(92)77992-2.

Conneely, M., D. P. Berry, R. Sayers, J. P. Murphy, I. Lorenz, M. L. Doherty, and E. Kennedy. 2013. Factors associated with the con- centration of immunoglobulin $\mathrm{G}$ in the colostrum of dairy cows. Animal 7:1824-1832. https://doi.org/10.1017/S1751731113001444.

Contarini, G., M. Povolo, V. Pelizzola, L. Monti, A. Bruni, L. Passolungo, F. Abeni, and L. Degano. 2014. Bovine colostrum: Changes in lipid constituents in the first 5 days after parturition. J. Dairy Sci. 97:5065-5072. https://doi.org/10.3168/jds.2013-7517.

Copping, K. J., J. Hernandez-Medrano, A. Hoare, K. Hummitzsch, I. C. McMillen, J. L. Morrison, R. J. Rodgers, and V. E. A. Perry. 2020. Maternal periconceptional and first trimester protein restriction in beef heifers: effects on placental parameters and fetal and neonatal calf development. Reprod. Fertil. Dev. 32:495-507. https: //doi.org/10.1071/RD19017.

Dahl, G. E., A. L. Skibiel, and J. Laporta. 2019. In utero heat stress programs reduced performance and health in calves. Vet. Clin. North Am. Food Anim. Pract. 35:343-353. https://doi.org/10 $.1016 /$ j.cvfa.2019.02.005.

Davis Rincker, L., M. J. VandeHaar, C. A. Wolf, J. S. Liesman, L. T. Chapin, and M. S. Weber Nielsen. 2011. Effect of intensified feeding of heifer calves on growth, pubertal age, calving age, milk yield, and economics. J. Dairy Sci. 94:3554-3567. https://doi.org/ 10.3168/jds.2010-3923.

De Paula Vieira, A., V. Guesdon, A. M. de Passille, M. A. G. von Keyserlingk, and D. M. Weary. 2008. Behavioural indicators of hunger in dairy calves. Appl. Anim. Behav. Sci. 109:180-189. https://doi .org/10.1016/j.applanim.2007.03.006.

De Vries, A., and M. Marcondes. 2020. Review: Overview of factors affecting productive lifespan of dairy cows. Animal 14(Suppl. 1):s155-S164. https://doi.org/10.1017/S1751731119003264.

Dennis, T. S., F. X. Suarez-Mena, T. M. Hill, J. D. Quigley, R. L. Schlotterbeck, and L. Hulbert. 2018. Effect of milk replacer feeding rate, age at weaning, and method of reducing milk replacer to weaning on digestion, performance, rumination, and activity in dairy calves to 4 months of age. J. Dairy Sci. 101:268-278. https:/ /doi.org/10.3168/jds.2017-13692.

De Vries, A., and M. Marcondes. 2020. Review: Overview of factors affecting productive lifespan of dairy cows. Animal 14(Suppl. 1):S155-S164. https://doi.org/10.1017/S1751731119003264.

Du, M., J. Tong, J. Zhao, K. R. Underwood, M. Zhu, S. P. Ford, and P. W. Nathanielsz. 2010. Fetal programming of skeletal muscle development in ruminant animals. J. Anim. Sci. 88(E. Suppl.):E51-E60. https://doi.org/10.2527/jas.2009.2311.

Duarte, M. S., M. P. Gionbelli, P. V. R. Paulino, N. V. L. Serão, T. S. Martins, P. I. S. Tótaro, C. A. Neves, S. C. Valadares Filho, M. V. Dodson, M. Zhu, and M. Du. 2013. Effects of maternal nutrition on development of gastrointestinal tract of bovine fetus at different stages of gestation. Livest. Sci. 153:60-65. https://doi.org/10 $.1016 /$ j.livsci.2013.01.006.

Dunn, A., A. Ashfield, B. Earley, M. Welsh, A. Gordon, and S. J. Morrison. 2017. Evaluation of factors associated with immunoglobulin $\mathrm{G}$, fat, protein, and lactose concentrations in bovine colostrum and colostrum management practices in grassland-based dairy systems in Northern Ireland. J. Dairy Sci. 100:2068-2079. https://doi.org/ $10.3168 /$ jds.2016-11724.

Echeverry-Munera, J., L. N. Leal, J. N. Wilms, H. Berends, J. H. C. Costa, M. A. Steele, and J. Martin-Tereso. 2021. Effect of partial exchange of lactose with fat in milk replacer on ad libitum feed intake and performance in dairy calves. J. Dairy Sci. 104:5432-5444. https://doi.org/10.3168/jds.2020-19485.

Eckert, E., H. E. Brown, K. E. Leslie, T. J. DeVries, and M. A. Steele. 2015. Weaning age affects growth, feed intake, gastrointestinal development, and behavior in Holstein calves fed an elevated plane of nutrition during the preweaning stage. J. Dairy Sci. 98:6315-6326. https://doi.org/10.3168/jds.2014-9062.

Elolimy, A., A. Alharthi, M. Zeineldin, C. Parys, A. Helmbrecht, and J. J. Loor. 2019. Supply of methionine during late-pregnancy alters fetal microbiota and metabolome in neonatal dairy calves without changes in daily feed intake. Front. Microbiol. 10:2159-2179. https: //doi.org/10.3389/fmicb.2019.02159.

Engfer, M. B., B. Stahl, B. Finke, G. Sawatzki, and H. Daniel. 2000. Human milk oligosaccharides are resistant to enzymatic hydrolysis 
in the upper gastrointestinal tract. Am. J. Clin. Nutr. 71:15891596. https://doi.org/10.1093/ajcn/71.6.1589.

Erickson, P. S., J. L. Anderson, K. F. Kalscheur, G. J. Lascano, M. S. Akins, and A. J. Heinrichs. 2020. Symposium review: Strategies to improve the efficiency and profitability of heifer raising. J. Dairy Sci. 103:5700-5708. https://doi.org/10.3168/jds.2019-17419.

Esselburn, K. M., K. M. O'Diam, T. M. Hill, H. G. Bateman II, J. M. Aldrich, R. L. Schlotterbeck, and K. M. Daniels. 2013. Intake of specific fatty acids and fat alters growth, health, and titers following vaccination in dairy calves. J. Dairy Sci. 96:5826-5835. https:/ /doi.org/10.3168/jds.2013-6608.

Faber, S. N., N. E. Faber, T. C. McCauley, and R. L. Ax. 2005. Case study: Effects of colostrum ingestion and lactational performance. Appl. Anim. Sci. 21:420-425. https://doi.org/10.15232/S1080 -7446(15)31240-7.

Feeney, S., J. Q. Gerlach, H. Slattery, M. Kilcoyne, R. M. Hickey, and L. Joshi. 2019. Lectin microarray profiling and monosaccharide analysis of bovine milk immunoglobulin $\mathrm{G}$ oligosaccharides during the first 10 days of lactation. Food Sci. Nutr. 7:1564-1572. https:/ /doi.org/10.1002/fsn3.950.

Ferrell, C. L., W. N. Garrett, N. Hinman, and G. Grichting. 1976. Energy utilization by pregnant and non-pregnant heifers. J. Anim. Sci. 42:937-950. https://doi.org/10.2527/jas1976.424937x.

Fischer, A. J., N. Malmuthuge, L. L. Guan, and M. A. Steele. 2018. Short communication: The effect of heat treatment of bovine colostrum on the concentration of oligosaccharides in colostrum and in the intestine of neonatal male Holstein calves. J. Dairy Sci. 101:401-407. https://doi.org/10.3168/jds.2017-13533.

Fischer, A. J., C. Villot, J. K. van Niekerk, T. T. Yohe, D. L. Renaud, and M. A. Steele. 2019. Invited Review: Nutritional regulation of gut function in dairy calves: From colostrum to weaning. Appl. Anim. Sci. 35:498-510. https://doi.org/10.15232/aas.2019-01887.

Fischer-Tlustos, A. J., K. Hertogs, J. K. Van Niekerk, M. Nagorske, D. M. Haines, and M. A. Steele. 2020. Oligosaccharide concentrations in colostrum, transition milk, and mature milk of primi- and multi-parous Holstein cows during the first week of lactation. J. Dairy Sci. 103:3683-3695. https://doi.org/10.3168/jds.2019-17357.

Fischer-Tlustos, A. J., A. J. Lopez Cabus, K. S. Hare, K. Wood, and M. Steele. 2021. Invited Review: Effects of colostrum management on transfer of passive immunity and the potential role of colostral bioactive components on neonatal calf development and metabolism. Can. J. Anim. Sci. https://doi.org/10.1139/CJAS-2020-0149.

Flower, F. C., and D. M. Weary. 2001. Effects of early separation on the dairy cow and calf: 2 . Separation at 1 day and 2 weeks after birth. Appl. Anim. Behav. Sci. 70:275-284. https://doi.org/10 .1016/S0168-1591(00)00164-7.

Ford, J. A. Jr., and C. S. Park. 2001. Nutritionally directed compensatory growth enhances heifer development and lactation potential. J. Dairy Sci. 84:1669-1678. https://doi.org/10.3168/jds.S0022 -0302(01)74602-4.

Frayn, K. N., F. Karpe, B. A. Fielding, I. A. Macdonald, and S. W. Coppack. 2003. Integrative physiology of human adipose tissue. Int. J. Obes. 27:875-888. https://doi.org/10.1038/sj.ijo.0802326.

Gabler, M. T., and A. J. Heinrichs. 2003. Dietary protein to metabolizable energy ratios on feed efficiency and structural growth of prepubertal Holstein heifers. J. Dairy Sci. 86:268-274. https://doi .org/10.3168/jds.S0022-0302(03)73605-4.

Gallier, S., K. Vocking, J. A. Post, B. Van De Heijning, D. Acton, E. M. Van Der Beek, and T. Van Baalen. 2015. A novel infant milk formula concept: Mimicking the human milk fat globule structure. Colloids Surf. B Biointerfaces 136:329-339. https://doi.org/ 10.1016/j.colsurfb.2015.09.024.

Geiger, A. J., C. Leonardi, and A. Lago. 2019. Supplementing dairy calves with colostral immunoglobulins for 14 days reduces death loss and antibiotic usage. J. Dairy Sci. 102:182 (Abstr.).

Gelsinger, S. L., W. K. Coblentz, G. I. Zanton, R. K. Ogden, and M. S. Akins. 2020. Physiological effects of starter-induced ruminal acidosis in calves before, during, and after weaning. J. Dairy Sci. 103:2762-2772. https://doi.org/10.3168/jds.2019-17494.

Gelsinger, S. L., A. J. Heinrichs, and C. M. Jones. 2016. A metaanalysis of the effects of preweaned calf nutrition and growth on first-lactation performance. J. Dairy Sci. 99:6206-6214. https:// doi.org/10.3168/jds.2015-10744.

Gerrits, W. J. J. 2019. Symposium review: Macronutrient metabolism in the growing calf. J. Dairy Sci. 102:3684-3691. https://doi.org/ $10.3168 /$ jds.2018-15261

Gill, R. K., S. Mahmood, J. P. Nagpaul, and A. Mahmood. 1999. Functional role of sialic acid in IgG binding to microvillus membranes in neonatal rat intestine. Biol. Neonate 76:55-64. https:// doi.org/10.1159/000014131.

Gionbelli, T. R. S., C. M. Veloso, P. P. Rotta, S. C. Valadares Filho, B. C. Carvalho, M. I. Marcondes, C. S. Cunha, M. A. S. Novaes, L. D. Prezotto, M. S. Duarte, and M. P. Gionbelli. 2018. Fetal development of skeletal muscle in bovines as a function of maternal nutrition, fetal sex and gestational age. J. Anim. Physiol. Anim. Nutr. (Berl.) 102:545-556. https://doi.org/10.1111/jpn.12786.

Godden, S. M., J. E. Lombard, and A. R. Woolums. 2019. Colostrum management for dairy calves. Vet. Clin. North Am. Food Anim. Pract. 35:535-556. https://doi.org/10.1016/j.cvfa.2019.07.005.

Godden, S. M., D. J. Smolenski, M. Donahue, J. M. Oakes, R. Bey, S. Wells, S. Sreevatsan, J. Stabel, and J. Fetrow. 2012. Heat-treated colostrum and reduced morbidity in preweaned dairy calves: Results of a randomized trial and examination of mechanisms of effectiveness. J. Dairy Sci. 95:4029-4040. https://doi.org/10.3168/ jds.2011-5275.

González-Recio, O., E. Ugarte, and A. Bach. 2012. Trans-generational effect of maternal lactation during pregnancy: A Holstein cow model. PLoS One 7:e51816. https://doi.org/10.1371/journal.pone .0051816 .

Gooden, J. M., M. R. Brandon, P. E. Hartmann, and A. K. Lascelles. 1971. Factors affecting lipid output and flow of thoracic duct lymph in newborn calves. Aust. J. Biol. Sci. 24:1309-1318. https:/ /doi.org/10.1071/BI9711309.

Gressley, T. F., M. B. Hall, and L. E. Armentano. 2011. Ruminant Nutrition Symposium: Productivity, digestion, and health responses to hindgut acidosis in ruminants. J. Anim. Sci. 89:1120-1130. https://doi.org/10.2527/jas.2010-3460.

Groen, M. J., M. A. Steele, and T. J. Devries. 2015. Short communication: Effect of straw inclusion rate in a dry total mixed ration on the behavior of weaned dairy calves. J. Dairy Sci. 98:2693-2700. https://doi.org/10.3168/jds.2014-8978.

Guilloteau, P., V. Romé, L. Le Normand, G. Savary, and R. Zabielski. 2004. Is Na-butyrate a growth factor in the preruminant calf? Preliminary results. J. Anim. Feed Sci. 13(Suppl. 1):393-396. https:/ /doi.org/10.22358/jafs/73945/2004.

Guilloteau, P., R. Toullec, J. F. Grongnet, P. Patureau-Mirand, J. Prugnaud, and D. Sauvant. 1986. Digestion of milk, fish, and soyabean protein in the preruminant calf: flow of digesta, apparent digestibility at the end of the ileum and amino acid composition of ileal digesta. Br. J. Nutr. 55:571-592. https://doi.org/10.1079/ BJN19860063.

Gulliksen, S. M., K. I. Lie, L. Sølverød, and O. Østerås. 2008. Risk factors associated with colostrum quality in Norwegian dairy cows. J. Dairy Sci. 91:704-712. https://doi.org/10.3168/jds.2007-0450.

Guy, M. A., T. B. McFadden, D. C. Cockrell, and T. E. Besser. 1994. Regulation of colostrum formation in beef and dairy cows. J. Dairy Sci. 77:3002-3007. https://doi.org/10.3168/jds.S0022 -0302(94)77241-6.

Hageman, J. H. J., M. Danielsen, A. G. Nieuwenhuizen, A. L. Feitsma, and T. K. Dalsgaard. 2019. Comparison of bovine milk fat and vegetable fat for infant formula: Implications for infant health. Int. Dairy J. 92:37-49. https://doi.org/10.1016/j.idairyj.2019.01.005.

Haisan, J., Y. Inabu, W. Shi, and M. Oba. 2019. Effects of feeding a high- or moderate-starch prepartum diet to cows on newborn dairy heifer calf responses to intravenous glucose tolerance tests early in life. J. Dairy Sci. 102:8931-8940. https://doi.org/10.3168/ jds.2018-16226.

Hamilton, R. K., and A. M. Raven. 1972. Effects of interesterification and fatty acid supplementation on the digestibility of tallow in milk replacers for calves. J. Sci. Food Agric. 23:831-844. https:// doi.org/10.1002/jsfa.2740230704. 
Hammon, H. M., and J. W. Blum. 2002. Feeding different amounts of colostrum or only milk replacer modify receptors of intestinal insulin-like growth factors and insulin in neonatal calves. Domest. Anim. Endocrinol. 22:155-168. https://doi.org/10.1016/S0739 -7240(02)00122-4.

Han, L., A. J. Heinrichs, A. De Vries, and C. D. Dechow. 2021. Relationship of body weight at first calving with milk yield and herd life. J. Dairy Sci. 104:397-404. https://doi.org/10.3168/jds.2020 $-19214$.

Hasegawa, R., I. Iwase, T. Takagi, M. Kondo, M. Matsui, and C. Kawashima. 2019. Insulin resistance: Relationship between indices during late gestation in dairy cows and effects on newborn metabolism. Anim. Sci. J. 90:1544-1555. https://doi.org/10.1111/ asj.13300.

Heinrichs, A. J., G. I. Zanton, G. J. Lascano, and C. M. Jones. 2017. A 100-Year Review: A century of dairy heifer research. J. Dairy Sci. 100:10173-10188. https://doi.org/10.3168/jds.2017-12998.

Hill, S. R., K. F. Knowlton, K. M. Daniels, R. E. James, R. E. Pearson, A. V. Capuco, and R. M. Akers. 2008. Effects of milk replacer composition on growth, body composition, and nutrient excretion in preweaned Holstein heifers. J. Dairy Sci. 91:3145-3155. https:/ /doi.org/10.3168/jds.2007-0860.

Hill, T. M., H. G. Bateman Ii., J. M. Aldrich, and R. L. Schlotterbeck. 2009. Effect of consistency of nutrient intake from milk and milk replacer on dairy calf performance. Prof. Anim. Sci. 25:85-92. https://doi.org/10.15232/S1080-7446(15)30679-3.

Hiltz, R. L., and A. H. Laarman. 2019. Effect of butyrate on passive transfer of immunity in dairy calves. J. Dairy Sci. 102:4190-4197. https://doi.org/10.3168/jds.2018-15555.

Hochberg, Z., R. Feil, M. Constancia, M. Fraga, C. Junien, J.-C. Carel, P. Boileau, Y. Le Bouc, C. L. Deal, K. Lillycrop, R. Scharfmann, A. Sheppard, M. Skinner, M. Szyf, R. A. Waterland, D. J. Waxman, E. Whitelaw, K. Ong, and K. Albertsson-Wikland. 2011. Child health, developmental plasticity, and epigenetic programming. Endocr. Rev. 32:159-224. https://doi.org/10.1210/er.2009 -0039 .

Hof, G. 1980. An investigation into the extent to which various dietary components, particularly lactose, are related to the incidence of diarrhoea in milk-fed calves. Doctoral dissertation. Wageningen University, Wageningen.

Hoffman, P. C., K. A. Weigel, and R. M. Wernberg. 2008. Evaluation of equations to predict dry matter intake of dairy heifers. J. Dairy Sci. 91:3699-3709. https://doi.org/10.3168/jds.2007-0644.

Hostettler-Allen, R. L., L. Tappy, and J. W. Blum. 1994. Insulin resistance, hyperglycemia, and glucosuria in intensively milk-fed calves. J. Anim. Sci. 72:160-173. https://doi.org/10.2527/1994.721160x.

House, W. A., and A. W. Bell. 1993. Mineral accretion in the fetus and adnexa during late gestation in Holstein cows. J. Dairy Sci 76:2999-3010. https://doi.org/10.3168/jds.S0022-0302(93)77639 -0 .

Hugi, D., S. H. Gut, and J. W. Blum. 1997. Blood metabolites and hormones - especially glucose and insulin - in veal calves: Effects of age and nutrition. Zentralbl. Veterinärmed. A 44:407-416. https: //doi.org/10.1111/j.1439-0442.1997.tb01126.x.

Hulbert, L. E., and S. J. Moisa. 2016. Stress, immunity, and the management of calves. J. Dairy Sci. 99:3199-3216. https://doi.org/10 $.3168 /$ jds.2015-10198.

Husnain, A., and J. E. P. Santos. 2019. Meta-analysis of the effects of prepartum dietary protein on performance of dairy cows. J. Dairy Sci. 102:9791-9813. https://doi.org/10.3168/jds.2018-16043.

Inabu, Y., J. Pyo, S. Pletts, L. L. Guan, M. A. Steele, and T. Sugino. 2019. Effect of extended colostrum feeding on plasma glucagon-like peptide-1 concentration in newborn calves. J. Dairy Sci. 102:4619 4627. https://doi.org/10.3168/jds.2018-15616.

Izumi, H., N. Kosaka, T. Shimizu, K. Sekine, T. Ochiya, and M. Takase. 2014. Time-dependent expression profiles of microRNAs and mRNAs in rat milk whey. PLoS One 9:e88843. https://doi.org/10 .1371/journal.pone.0088843.

Jaeger, B. M., D. Ziegler, D. Schimek, B. Ziegler, M. Raeth, H. Chester-Jones, and D. P. Casper. 2020. Growth performance of newborn dairy calves fed a milk replacer with 2 protein concentrations at 2 feeding rates. Appl. Anim. Sci. 36:48-56. https://doi.org/10 .15232 /aas.2019-01866.

Jasper, J., and D. M. Weary. 2002. Effects of ad libitum milk intake on dairy calves. J. Dairy Sci. 85:3054-3058. https://doi.org/10.3168/ jds.S0022-0302(02)74391-9.

Jensen, M. B., and L. Holm. 2003. The effect of milk flow rate and milk allowance on feeding related behavior in dairy calves fed by computer-controlled milk feeders. Appl. Anim. Behav. Sci. 82:87100. https://doi.org/10.1016/S0168-1591(03)00054-6.

Jodal, M., and O. Lundgren. 1986. Countercurrent mechanisms in the mammalian gastrointestinal tract. Gastroenterology 91:225-241. https://doi.org/10.1016/0016-5085(86)90463-4.

Kahyani, A., G. R. Ghorbani, M. Alikhani, E. Ghasemi, A. Sadeghi-Sefidmazgi, K. A. Beauchemin, and S. M. Nasrollahi. 2019. Performance of dairy cows fed diets with similar proportions of undigested neutral detergent fiber with wheat straw substituted for alfalfa hay, corn silage, or both. J. Dairy Sci. 102:10903-10915. https://doi.org/10.3168/jds.2019-16869.

Kamal, M. M., M. Van Eetvelde, H. Bogaert, M. Hostens, L. Vandaele, M. Shamsuddin, and G. Opsomer. 2015. Environmental factors and dam characteristics associated with insulin sensitivity and insulin secretion in newborn Holstein calves. Animal 9:1490-1499. https://doi.org/10.1017/S1751731115000701.

Kamal, M. M., M. Van Eetvelde, E. Depreester, M. Hostens, L. Vandaele, and G. Opsomer. 2014. Age at calving in heifers and level of milk production during gestation in cows are associated with the birth size of Holstein calves. J. Dairy Sci. 97:5448-5458. https:// doi.org/10.3168/jds.2014-7898.

Kargar, S., M. Roshan, S. M. Ghoreishi, A. Akhlaghi, M. Kanani, A. R. Abedi Shams-Abadi, and M. H. Ghaffari. 2020. Extended colostrum feeding for 2 weeks improves growth performance and reduces the susceptibility to diarrhea and pneumonia in neonatal Holstein dairy calves. J. Dairy Sci. 103:8130-8142. https://doi .org/10.3168/jds.2020-18355.

Kavanaugh, D. W., J. O'Callaghan, L. F. Butto, H. Slattery, J. Lane, M. Clyne, M. Kane, L. Joshi, and R. M. Hickey. 2013. Exposure of Bifidobacterium longum ssp. infantis to milk oligosaccharides increases adhesion to epithelial cells and induces a substantial transcriptional response. PLoS One 8:e67224. https://doi.org/10.1371/ journal.pone.0067224.

Kawashima, C., M. Munakata, T. Shimizu, A. Miyamoto, K. Kida, and M. Matsui. 2016. Relationship between the degree of insulin resistance during late gestation and postpartum performance in dairy cows and factors that affect growth and metabolic status of their calves. J. Vet. Med. Sci. 78:739-745. https://doi.org/10 $.1292 /$ jvms.15-0583.

Kertz, A. F., T. M. Hill, J. D. Quigley III, A. J. Heinrichs, J. G. Linn, and J. K. Drackley. 2017. A 100-Year Review: Calf nutrition and management. J. Dairy Sci. 100:10151-10172. https://doi.org/10 $.3168 /$ jds.2017-13062.

Khan, M. A., A. Bach, D. M. Weary, and M. A. G. von Keyserlingk. 2016. Invited review: Transitioning from milk to solid feed in dairy heifers. J. Dairy Sci. 99:885-902. https://doi.org/10.3168/jds.2015 $-9975$.

Khan, M. A., H. J. Lee, W. S. Lee, H. S. Kim, S. B. Kim, K. S. Ki, J. K. Ha, H. G. Lee, and Y. J. Choi. 2007. Pre- and postweaning performance of Holstein female calves fed milk through step-down and conventional methods. J. Dairy Sci. 90:876-885. https://doi .org/10.3168/jds.S0022-0302(07)71571-0.

Khan, M. A., D. M. Weary, and M. A. G. von Keyserlingk. 2011. Invited review: Effects of milk ration on solid feed intake, weaning, and performance in dairy heifers. J. Dairy Sci. 94:1071-1081. https://doi.org/10.3168/jds.2010-3733.

Kiezebrink, D. J., A. M. Edwards, T. C. Wright, J. P. Cant, and V. R. Osborne. 2015. Effect of enhanced whole-milk feeding in calves on subsequent first-lactation performance. J. Dairy Sci. 98:349-356. https://doi.org/10.3168/jds.2014-7959.

Kuzawa, C. W. 1998. Adipose tissue in human infancy and childhood: An evolutionary perspective. Am. J. Phys. Anthropol. 107(Suppl. 27):177-209. https://doi.org/10.1002/(SICI)1096-8644(1998)107: $27+<177::$ AID-AJPA7 $>3.0$. CO;2-B. 
Laarman, A. H., T. Sugino, and M. Oba. 2012. Effects of starch content of calf starter on growth and rumen $\mathrm{pH}$ in Holstein calves during the weaning transition. J. Dairy Sci. 95:4478-4487. https:/ /doi.org/10.3168/jds.2011-4822.

Labussière, E., J. van Milgen, C. F. M. de Lange, and J. Noblet. 2011. Maintenance energy requirements of growing pigs and calves are influenced by feeding level. J. Nutr. 141:1855-1861. https://doi .org/10.3945/jn.111.141291.

Lane, M. A., R. L. Baldwin IV, and B. W. Jesse. 2000. Sheep rumen metabolic development in response to age and dietary treatments. J. Anim. Sci. 78:1990-1996. https://doi.org/10.2527/2000 $.7871990 x$.

Lane, M. A., R. L. Baldwin IV, and B. W. Jesse. 2002. Developmental changes in ketogenic enzyme gene expression during sheep rumen development. J. Anim. Sci. 80:1538-1544. https://doi.org/10 $.2527 / 2002.8061538 \mathrm{x}$.

Langel, S. N., W. A. Wark, S. N. Garst, R. E. James, M. L. McGilliard, C. S. Petersson-Wolfe, and I. Kanevsky-Mullarky. 2016. Effect of feeding whole compared with cell-free colostrum on calf immune status: Vaccination response. J. Dairy Sci. 99:3979-3994. https://doi.org/10.3168/jds.2015-9892.

Lean, I. J., M. B. de Ondarza, C. J. Sniffen, J. E. P. Santos, and K. E. Griswold. 2018. Meta-analysis to predict the effects of metabolizable amino acids on dairy cattle performance. J. Dairy Sci. 101:340-364. https://doi.org/10.3168/jds.2016-12493.

Leane, S., M. M. Herlihy, F. Curran, J. Kenneally, N. Forde, C. A. Simintiras, R. G. Sturmey, M. C. Lucy, P. Lonergan, and S. T. Butler. 2018. The effect of exogenous glucose infusion on early embryonic development in lactating dairy cows. J. Dairy Sci. 101:11285-11296. https://doi.org/10.3168/jds.2018-14894.

Lee, H. J., M. A. Khan, W. S. Lee, S. H. Yang, S. B. Kim, K. S. Ki, H. S. Kim, J. K. Ha, and Y. J. Choi. 2009. Influence of equalizing the gross composition of milk replacer to that of whole milk on the performance of Holstein calves. J. Anim. Sci. 87:1129-1137. https: //doi.org/10.2527/jas.2008-1110.

Lecce, J. G., and D. O. Morgan. 1962. Effect of dietary regimen on cessation of intestinal absorption of large molecules (closure) in the neonatal pig and lamb. J. Nutr. 78:263-268. https://doi.org/ $10.1093 / \mathrm{jn} / 78.3 .263$.

LeMaster, C. T., R. K. Taylor, R. E. Ricks, and N. M. Long. 2017. The effects of late gestation maternal nutrient restriction with or without protein supplementation on endocrine regulation of newborn and postnatal beef calves. Theriogenology 87:64-71. https:// doi.org/10.1016/j.theriogenology.2016.08.004.

Li, R. W., E. E. Connor, C. Li, R. L. Baldwin VI, and M. E. Sparks. 2012. Characterization of the rumen microbiota of pre-ruminant calves using metagenomic tools. Environ. Microbiol. 14:129-139. https://doi.org/10.1111/j.1462-2920.2011.02543.x.

Liang, G., N. Malmuthuge, T. B. McFadden, H. Bao, P. J. Griebel, P. Stothard, and L. L. Guan. 2014. Potential regulatory role of microRNAs in the development of bovine gastrointestinal tract during early life. PLoS One 9:e92592. https://doi.org/10.1371/ journal.pone.0092592.

Liebler-Tenorio, E. M., G. Riedel-Caspari, and J. F. Pohlenz. 2002. Uptake of colostral leukocytes in the intestinal tract of newborn calves. Vet. Immunol. Immunopathol. 85:33-40. https://doi.org/ 10.1016/S0165-2427(01)00404-4.

Ling, T., M. Hernandez-Jover, L. M. Sordillo, and A. Abuelo. 2018. Maternal late-gestation metabolic stress is associated with changes in immune and metabolic responses of dairy calves. J. Dairy Sci. 101:6568-6580. https://doi.org/10.3168/jds.2017-14038.

Lombard, J., N. Urie, F. Garry, S. Godden, J. Quigley, T. Earleywine, S. McGuirk, D. Moore, M. Branan, M. Chamorro, G. Smith, C. Shivley, D. Catherman, D. Haines, A. J. Heinrichs, R. James, J. Maas, and K. Sterner. 2020. Consensus recommendations on calf- and herd-level passive immunity in dairy calves in the United States. J. Dairy Sci. 103:7611-7624. https://doi.org/10.3168/jds 2019-17955.

Lopez, C., C. Cauty, and F. Guyomarc'h. 2015. Organization of lipids in milks, infant milk formulas and various dairy products: Role of technological processes and potential impacts. Dairy Sci. Technol. 95:863-893. https://doi.org/10.1007/s13594-015-0263-0.

MacPherson, J. A. R., H. Berends, L. N. Leal, J. P. Cant, J. MartínTereso, and M. A. Steele. 2016. Effect of plane of milk replacer intake and age on glucose and insulin kinetics and abomasal emptying in female Holstein Friesian dairy calves fed twice daily. J. Dairy Sci. 99:8007-8017. https://doi.org/10.3168/jds.2015-10826.

Mann, S., F. A. Leal Yepes, T. R. Overton, A. L. Lock, S. V. Lamb, J. J. Wakshlag, and D. V. Nydam. 2016. Effect of dry period dietary energy level in dairy cattle on volume, concentrations of immunoglobulin G, insulin, and fatty acid composition of colostrum. J. Dairy Sci. 99:1515-1526. https://doi.org/10.3168/jds.2015-9926.

Mavangira, V., and L. M. Sordillo. 2018. Role of lipid mediators in the regulation of oxidative stress and inflammatory responses in dairy cattle. Res. Vet. Sci. 116:4-14. https://doi.org/10.1016/j.rvsc.2017 .08 .002 .

McGrath, B. A., P. F. Fox, P. L. H. McSweeney, and A. L. Kelly. 2016. Composition and properties of bovine colostrum: A review. Dairy Sci. Technol. 96:133-158. https://doi.org/10.1007/s13594 $-015-0258-\mathrm{x}$.

Meale, S. J., L. N. Leal, J. Martin-Tereso, and M. A. Steele. 2015. Delayed weaning of Holstein bull calves fed an elevated plan of nutrition impacts feed intake, growth and potential markers of gastrointestinal development. Anim. Feed Sci. Technol. 209:268-273. https://doi.org/10.1016/j.anifeedsci.2015.08.008.

Meale, S. J., S. C. Li, P. Azevedo, H. Derakhshani, T. J. DeVries, J. C. Plaizier, M. A. Steele, and E. Khafipour. 2017b. Weaning age influences the severity of gastrointestinal microbiome shifts in dairy calves. Sci. Rep. 7:198. https://doi.org/10.1038/s41598-017 $-00223-7$.

Meale, S. J., F. Chaucheyras-Durand, H. Berends, L. L. Guan, and M. A. Steele. 2017a. From pre-to postweaning: Trasformation of the young calf's gastrointestinal tract. J. Dairy Sci. 100:5984-5995. https://doi.org/10.3168/jds.2016-12474.

Mertens, D. R. 2016. Using uNDF to predict dairy cow performance and design rations. Accessed Oct. 8, 2020. http://www .wiagribusiness.org/fourstatedairy/2016/4_Mertens.pdf.

Miqueo, E., T. M. Torrezan, N. B. Rocha, M. R. De Paula, F. L. M. Silva, P. H. M. Rodrigues, and C. M. M. Bittar. 2017. Increase in crude protein content of milk replacers with vegetable protein effect on health and dairy calves' performance. Am. J. Anim. Vet. Sci. 12:17-25. https://doi.org/10.3844/ajavsp.2017.17.25.

Mitchell, L. K., and A. J. Heinrichs. 2020. Feeding various forages and live yeast culture on weaned dairy calf intake, growth, nutrient digestibility, and ruminal fermentation. J. Dairy Sci. 103:8880-8897. https://doi.org/10.3168/jds.2020-18479.

Mitchell, L. K., C. M. Jones, and A. J. Heinrichs. 2020. Effect of converting weaned dairy calves from a component-fed diet to a total mixed ration on growth and nutrient digestibility. J. Dairy Sci 103:6190-6199. https://doi.org/10.3168/jds.2019-17980.

Moallem, U., D. Werner, H. Lehrer, M. Zachut, L. Livshitz, S. Yakoby, and A. Shamay. 2010. Long-term effects of ad libitum whole milk prior to weaning and prepubertal protein supplementation on skeletal growth rate and first-lactation milk production. J. Dairy Sci. 93:2639-2650. https://doi.org/10.3168/jds.2009-3007.

Molano, R. A., A. Saito, D. N. Luchini, and M. E. Van Amburgh. 2020. Effects of rumen-protected methionine or methionine analogs in starter on plasma metabolites, growth, and efficiency of Holstein calves from 14 to 91 d of age. J. Dairy Sci. 103:10136-10151. https: //doi.org/10.3168/jds.2020-18630.

Morrill, K. M., E. Conrad, A. Lago, J. Campbell, J. Quigley, and H. Tyler. 2012. Nationwide evaluation of quality and composition of colostrum on dairy farms in the United States. J. Dairy Sci. 95:3997-4005. https://doi.org/10.3168/jds.2011-5174.

Morrison, S. Y., J. M. Campbell, and J. K. Drackley. 2017. Amino acid supplementation of calf milk replacers containing plasma protein. J. Dairy Sci. 100:4637-4649. https://doi.org/10.3168/jds .2016-12402.

Nichols, K., A. Bannink, and J. Dijkstra. 2019. Energy and nitrogen balance of dairy cattle as affected by provision of different essential 
amino acid profiles at the same metabolizable protein supply. J. Dairy Sci. 102:8963-8976. https://doi.org/10.3168/jds.2019-16400.

Novo, S. M. F., J. F. D. R. Costa, C. C. Baccili, N. M. Sobreira, B. T. Silva, P. L. de Oliveira, D. J. Hurley, and V. Gomes. 2017. Effect of maternal cells transferred with colostrum on the health of neonate calves. Res. Vet. Sci. 112:97-104. https://doi.org/10.1016/j.rvsc 2017.01.025

NRC. 2001. Nutrient Requirements of Dairy Cattle. 7th rev. ed. Natl. Acad. Press.

O'Callaghan, T. F., M. O'Donovan, J. P. Murphy, K. Sugrue, D. Mannion, W. P. McCarthy, M. Timlin, K. N. Kilcawley, R. M. Hickey, and J. T. Tobin. 2020. Evolution of the bovine milk fatty acid profile - from colostrum to milk five days post parturition. Int Dairy J. 104:104655-104662. https://doi.org/10.1016/j.idairyj .2020 .104655 .

Ollivett, T. L., D. V. Nydam, T. C. Linden, D. D. Bowman, and M. E. Van Amburgh. 2012. Effect of nutritional plane on health and performance in dairy calves after experimental infection with Cryptosporidium parvum. J. Am. Vet. Med. Assoc. 241:1514-1520. https: //doi.org/10.2460/javma.241.11.1514.

Opgenorth, J., L. M. Sordillo, and M. J. Vandehaar. 2020. Colostrum supplementation with n-3 fatty acids and a-tocopherol alters plasma polyunsaturated fatty acid profile and decreases an indicator of oxidative stress in newborn calves. J. Dairy Sci. 103:3545-3553. https://doi.org/10.3168/jds.2019-17380.

Palczynski, L. J., E. C. L. Bleach, M. L. Brennan, and P. A. Robinson. 2020. Appropriate dairy calf feeding from birth to weaning: "It's an investment for the future". Animal 10:116-136. https://doi.org/ $10.3390 /$ ani10010116.

Pantophlet, A. J., W. J. J. Gerrits, R. J. Vonk, and J. J. G. C. van den Borne. 2016a. Substantial replacement of lactose with fat in a high-lactose milk replacer diet increases liver fat accumulation but does not affect insulin sensitivity in veal calves. J. Dairy Sci. 99:10022-10032. https://doi.org/10.3168/jds.2016-11524.

Pantophlet, A. J., M. S. Gilbert, J. J. van den Borne, W. J. Gerrits, H. Roelofsen, M. G. Priebe, and R. J. Vonk. 2016b. Lactose in milk replacer can partly be replaced by glucose, fructose, or glycerol without affecting insulin sensitivity in veal calves. J. Dairy Sci. 99:3072-3080. https://doi.org/10.3168/jds.2015-10277.

Parrish, D. B., G. H. Wise, J. S. Hughes, and F. W. Atkeson. 1950 Properties of the colostrum of the dairy cow. V. Yield, specific gravity and concentrations of total solids and its various components of colostrum and early milk. J. Dairy Sci. 33:457-465. https: //doi.org/10.3168/jds.S0022-0302(50)91921-7.

Pillai, S. M. A. K. Jones, M. L. Hoffman, K. K. McFadden, S. A. Reed, S. A. Zinn, and K. E. Govoni. 2017. Fetal and organ development at gestational days 45, 90, 135 and at birth of lambs exposed to under- or over-nutrition during gestation. Transl. Anim. Sci. 1:16-25. https://doi.org/10.2527/tas2016.0002.

Pyo, J., K. Hare, S. Pletts, Y. Inabu, D. Haines, T. Sugino, L. L. Guan, and M. Steele. 2020. Feeding colostrum or a 1: 1 colostrum: milk mixture for 3 days postnatal increases small intestinal development and minimally influences plasma glucagon-like peptide-2 and serum insulin-like growth factor-1 concentrations in Holstein bull calves. J. Dairy Sci. 103:4236-4251. https://doi.org/10.3168/ jds.2019-17219.

Quigley, J. 2004. The role of oral immunoglobulins in systemic and intestinal immunity of neonatal calves. Proc. Professional Dairy Heifer Growers Assoc. Accessed Aug. 18, 2020. https://spac.adsa.org/showpdf.asp?file= proceedings + of + the $+2006+$ dairy + calf + and + heifer + association $\% 5$ Cquigley $3 \% 2$ Epdf.

Quigley, J. D., T. M. Hill, T. S. Dennis, F. X. Suarez-Mena, and R. L. Schlotterbeck. 2018. Effects of feeding milk replacer at 2 rates with pelleted, low-starch or texturized, high-starch starters on calf performance and digestion. J. Dairy Sci. 101:5937-5948. https:// doi.org/10.3168/jds.2017-13851.

Quigley, J. D., W. Hu, J. R. Knapp, T. S. Dennis, F. X. Suarez-Mena, and T. M. Hill. 2019a. Estimates of calf starter energy affected by consumption of nutrients. 1. Evaluation of models to predict changing digestion on energy content in calf starters. J. Dairy Sci. 102:2232-2241. https://doi.org/10.3168/jds.2018-15353.

Quigley, J. D., W. Hu, J. R. Knapp, T. S. Dennis, F. X. Suarez-Mena, and T. M. Hill. 2019b. Estimates of calf starter energy affected by consumption of nutrients. 2. Effect of changing digestion on energy content in calf starters. J. Dairy Sci. 102:2242-2253. https://doi .org/10.3168/jds.2018-15354.

Quigley, J. D. III, C. G. Schwab, and W. E. Hylton. 1985. Development of rumen function in calves: Nature of protein reaching the abomasum. J. Dairy Sci. 68:694-702. https://doi.org/10.3168/jds S0022-0302(85)80875-4.

Raeth, M., H. Chester-Jones, D. Ziegler, B. Ziegler, D. Schimek, D. L. Cook, G. Golombeski, and A. V. Grove. 2016. Pre-and postweaning performance and health of dairy calves fed milk replacers with differing protein sources. Prof. Anim. Sci. 32:833-841. https://doi .org/10.15232/pas.2016-01536.

Rauprich, A. B. E., H. M. Hammon, and J. W. Blum. 2000. Influence of feeding different amounts of first colostrum on metabolic, endocrine, and health status and on growth performance in neonatal calves. J. Anim. Sci. 78:896-908. https://doi.org/10.2527/ 2000.784896x.

Reber, A. J., A. Lockwood, A. R. Hippen, and D. J. Hurley. 2006. Colostrum induced phenotypic and trafficking changes in maternal mononuclear cells in a peripheral blood leukocyte model for study of leukocyte transfer to the neonatal calf. Vet. Immunol. Immunopathol. 109:139-150. https://doi.org/10.1016/j.vetimm.2005.08 .014 .

Renaud, D. L., M. A. Steele, R. Genore, S. M. Roche, and C. B. Winder. 2020. Passive immunity and colostrum management practices on Ontario dairy farms and auction facilities: A cross-sectional study. J. Dairy Sci. 103:8369-8377. https://doi.org/10.3168/jds .2020-18572.

Reynolds, L. P., P. P. Borowicz, J. S. Caton, M. S. Crouse, C. R. Dahlen, and A. K. Ward. 2019. Developmental programming of fetal growth and development. Vet. Clin. North Am. Food Anim. Pract. 35:229-247. https://doi.org/10.1016/j.cvfa.2019.02.006.

Roland, L., M. Drillich, D. Klein-Jobstl, and M. Iwersen. 2016. Invited review: Influence of climatic conditions on the development, performance, and health of calves. J. Dairy Sci. 99:2438-2452. https: //doi.org/10.3168/jds.2015-9901.

Rosadiuk, J. P., T. C. Bruinje, F. Moslemipur, A. J. Fischer-Tlustos, D. L. Renaud, D. J. Ambrose, and M. A. Steele. 2021. Differing planes of pre- and postweaning phase nutrition in Holstein heifers: I. Effects on feed intake, growth efficiency, and metabolic and development indicators. J. Dairy Sci. 104:1136-1152. https://doi .org/10.3168/jds.2020-18809.

Rosenberger, K., J. H. C. Costa, H. W. Neave, M. A. G. von Keyserlingk, and D. M. Weary. 2017. The effect of milk allowance on behavior and weight gains in dairy calves. J. Dairy Sci. 100:504-512 https://doi.org/10.3168/jds.2016-11195.

Rotta, P. P., S. C. Valadares Filho, T. R. S. Gionbelli, L. F. Costa e Silva, T. E. Engle, M. I. Marcondes, M. M. Campos, A. C. B. Menezes, and A. A. G. Lobo. 2015. Effects of day of gestation and feeding regimen in Holstein $\times$ Gyr cows: II. Maternal and fetal visceral organ mass. J. Dairy Sci. 98:3211-3223. https://doi.org/ $10.3168 /$ jds.2014-8282.

Sargeant, J. M., A. M. O'Connor, I. A. Gardner, J. S. Dickson, M. E. Torrence, I. R. Dohoo, S. L. Lefebvre, P. S. Morley, A. Ramirez, and K. Snedeker. 2010. The REFLECT statement: Reporting guidelines for randomized controlled trials in livestock and food safety: Explanation and elaboration. J. Food Prot. 73:579-603. https://doi.org/10.4315/0362-028X-73.3.579.

Saugstad, O. D. 2003. Oxygen toxicity at birth: The pieces are put together. Pediatr. Res. 54:789. https://doi.org/10.1203/01.PDR $.0000103390 .01854 .0 \mathrm{E}$.

Sejrsen, K., and S. Purup. 1997. Influence of prepubertal feeding level on milk yield potential of dairy heifers: A review. J. Anim. Sci. 75:828-835. https://doi.org/10.2527/1997.753828x.

Sguizzato, A. L. L., M. I. Marcondes, J. Dijkstra, S. de Campos Valadares Filho, M. M. Campos, F. S. Machado, B. C. Silva, and P. P. 
Rotta. 2020. Energy requirements for pregnant dairy cows. PLoS One 15:e0235619. https://doi.org/10.1371/journal.pone.0235619.

Shivley, C. B., J. E. Lombard, N. J. Urie, D. M. Haines, R. Sargent, C. A. Kopral, T. J. Earleywine, J. D. Olson, and F. B. Garry. 2018. Preweaned heifer management on US dairy operations: Part II. Factors associated with colostrum quality and passive transfer status of dairy heifer calves. J. Dairy Sci. 101:9185-9198. https:// doi.org/10.3168/jds.2017-14008.

Silper, B. F., A. M. Q. Lana, A. U. Carvalho, C. S. Ferreira, A. P. S. Franzoni, J. A. M. Lima, H. M. Saturnino, R. B. Reis, and S. G. Coelho. 2014. Effects of milk replacer feeding strategies on performance, ruminal development, and metabolism of dairy calves. J. Dairy Sci. 97:1016-1025. https://doi.org/10.3168/jds.2013-7201.

Silva, A. L., T. J. DeVries, L. O. Tedeschi, and M. I. Marcondes. 2019 Development of equations, based on milk intake, to predict starter feed intake of preweaned dairy calves. Animal 13:83-89. https:// doi.org/10.1017/S1751731118000666.

Skrzypek, T., S. Szymańczyk, K. Ferenc, W. Kazimierczak, K. Szczepaniak, and R. Zabielski. 2018. The contribution of vacuolated foetal-type enterocytes in the process of maturation of the small intestine in piglets. Invited Review. J. Anim. Feed Sci. 27:187-201. https://doi.org/10.22358/jafs/94167/2018.

Soberon, F., E. Raffrenato, R. W. Everett, and M. E. Van Amburgh. 2012. Preweaning milk replacer intake and effects on long-term productivity of dairy calves. J. Dairy Sci. 95:783-793. https://doi .org/10.3168/jds.2011-4391.

Soberon, F., and M. E. Van Amburgh. 2013. Lactation Biology Symposium: The effect of nutrient intake from milk or milk replacer of preweaned dairy calves on lactation milk yield as adults: A meta-analysis of current data. J. Anim. Sci. 91:706-712. https:// doi.org/10.2527/jas.2012-5834.

Stahel, P., H. Berends, L. N. Leal, and J. Martín-Tereso. 2019. Effect of replacing lactose with fat in milk replacer on abomasal emptying and glucose-insulin kinetics in male dairy calves. Appl. Anim. Sci. 35:586-595. https://doi.org/10.15232/aas.2019-01896.

Stamey, J. A., N. A. Janovick, A. F. Kertz, and J. K. Drackley. 2012. Influence of starter protein content on growth of dairy calves in an enhanced early nutrition program. J. Dairy Sci. 95:3327-3336. https://doi.org/10.3168/jds.2011-5107.

Steele, M. A., J. H. Doelman, L. N. Leal, F. Soberon, M. Carson, and J. A. Metcalf. 2017. Abrupt weaning reduces postweaning growth and is associated with alterations in gastrointestinal markers of development in dairy calves fed an elevated plane of nutrition during the preweaning period. J. Dairy Sci. 100:5390-5399. https:// doi.org/10.3168/jds.2016-12310.

Stott, G. H., D. B. Marx, B. E. Menefee, and G. T. Nightengale. 1979. Colostral immunoglobulin transfer in calves II. The rate of absorption. J. Dairy Sci. 62:1766-1773. https://doi.org/10.3168/ jds.S0022-0302(79)83495-5.

Su, H., M. S. Akins, N. M. Esser, R. Ogden, W. K. Coblentz, K. F. Kalscheur, and R. Hatfield. 2017. Effects of feeding alfalfa stemlage or wheat straw for dietary energy dilution on nutrient intake and digestibility, growth performance, and feeding behavior of Holstein dairy heifers. J. Dairy Sci. 100:7106-7115. https://doi.org/10 $.3168 /$ jds.2016-12448.

Suárez, B. J., C. G. Van Reenen, G. Beldman, J. van Delen, J. Dijkstra, and W. J. J. Gerrits. 2006a. Effects of supplementing concentrates differing in carbohydrate composition in veal calf diets: I. Animal performance and rumen fermentation characteristics. J. Dairy Sci. 89:4365-4375. https://doi.org/10.3168/jds.S0022 -0302(06)72483-3.

Suárez, B. J., C. G. Van Reenen, W. J. J. Gerrits, N. Stockhofe, A. M. van Vuuren, and J. Dijkstra. 2006b. Effects of supplementing concentrates differing in carbohydrate composition in veal calf diets: II. Rumen development. J. Dairy Sci. 89:4376-4386. https:// doi.org/10.3168/jds.S0022-0302(06)72484-5.

Suarez-Mena, F. X., T. M. Hill, C. M. Jones, and A. J. Heinrichs. 2016. Effect of forage provision on feed intake in dairy calves. Prof. Anim. Sci. 32:383-388. https://doi.org/10.15232/pas.2016-01502.

Sweeney, B. C., J. Rushen, D. M. Weary, and A. M. de Passillé. 2010. Duration of weaning, starter intake, and weight gain of dairy calves fed large amounts of milk. J. Dairy Sci. 93:148-152. https:/ /doi.org/10.3168/jds.2009-2427.

Thomas, T. J., D. M. Weary, and M. C. Appleby. 2001. Newborn and 5 -week old calves vocalize in response to milk deprivation. Appl. Anim. Behav. Sci. 74:165-173. https://doi.org/10.1016/S0168 -1591(01)00164-2.

Tikofsky, J. N., M. E. Van Amburgh, and D. A. Ross. 2001. Effect of varying carbohydrate and fat content of milk replacer on body composition of Holstein bull calves. J. Anim. Sci. 79:2260-2267. https://doi.org/10.2527/2001.7992260x.

Tsioulpas, A., A. D. Grandison, and M. J. Lewis. 2007. Changes in physical properties of bovine milk from the colostrum period to early lactation. J. Dairy Sci. 90:5012-5017. https://doi.org/10 $.3168 /$ jds.2007-0192.

Urie, N. J., J. E. Lombard, C. B. Shivley, C. A. Kopral, A. E. Adams, T. J. Earleywine, J. D. Olson, and F. B. Garry. 2018a. Preweaned heifer management on US dairy operations: Part I. Descriptive characteristics of preweaned heifer raising practices. J. Dairy Sci. 101:9168-9184. https://doi.org/10.3168/jds.2017-14010.

Urie, N. J., J. E. Lombard, C. B. Shivley, C. A. Kopral, A. E. Adams, T. J. Earleywine, J. D. Olson, and F. B. Garry. 2018b. Preweaned heifer management on US dairy operations: Part V. Factors associated with morbidity and mortality in preweaned dairy heifer calves. J. Dairy Sci. 101:9229-9244. https://doi.org/10.3168/jds .2017-14019.

USDA. 2011. Dairy heifer raiser - An overview of operations that specialize in raising dairy heifers. Animal and Plant Health Inspection Service-Veterinary Services, Ft. Collins, CO. https://www.aphis .usda.gov/animal_health/nahms/dairy/downloads/dairyheifer11/ HeiferRaiser_1.pdf.

USDA. 2016. Dairy cattle management practices in the United States, 2014. https://www.aphis.usda.gov/animal_health/nahms/dairy/ downloads/dairy14/Dairy14_dr_PartI.pdf.

Van Amburgh, M. E., F. Soberon, M. J. Meyer, and R. A. Molano. 2019. Symposium review: Integration of postweaning nutrient requirements and supply with composition of growth and mammary development in modern dairy heifers. J. Dairy Sci. 102:3692-3705. https://doi.org/10.3168/jds.2018-15270.

Van Eetvelde, M., M. Kamal, L. Vandaele, and G. Opsomer. 2017. Season of birth is associated with first-lactation milk yield in Holstein Friesian cattle. Animal 11:2252-2259. https://doi.org/10.1017/ S1751731117001021.

Van Eetvelde, M., and G. Opsomer. 2017. Innovative look at dairy heifer rearing: Effect of prenatal and post-natal environment on later performance. Reprod. Domest. Anim. 52(Suppl. 3):30-36. https://doi.org/10.1111/rda.13019.

Van Eetvelde, M., and G. Opsomer. 2020. Prenatal programming of later performance in dairy cattle. Vlaams Diergeneeskd. Tijdschr. 89:53-62. https://doi.org/10.21825/vdt.v89i1.15985.

Van Hese, I., K. Goossens, L. Vandaele, and G. Opsomer. 2020. Invited review: MicroRNAs in bovine colostrum - Focus on their origin and potential health benefits for the calf. J. Dairy Sci. 103:1-15. https://doi.org/10.3168/jds.2019-16959.

van Niekerk, J. K., M. Middeldorp, L. L. Guan, and M. A. Steele. 2021. Preweaning to postweaning rumen papillae structural growth, ruminal fermentation characteristics, and acute-phase proteins in calves. J. Dairy Sci. 104:3632-3645. https://doi.org/10.3168/jds .2020-19003.

Vermorel, M., C. Dardillat, J. Vernet, T. Saido, and C. Deminge. 1983. Energy metabolism and thermoregulation in the newborn calf. Ann. Rech. Vet. 14:382-389.

Weaver, D. M., J. W. Tyler, D. C. VanMetre, D. E. Hostetler, and G. M. Barrington. 2000. Passive transfer of colostral immunoglobulins in calves. J. Vet. Intern. Med. 14:569-577. https://doi.org/10 $.1111 /$ j.1939-1676.2000.tb02278.x.

Welboren, A. C., B. Hatew, O. Lopez-Campos, J. P. Cant, L. N. Leal, J. Martin-Tereso, and M. A. Steele. 2021. Effects of energy source in milk replacer on glucose metabolism of neonatal dairy calves. J. Dairy Sci. 104:5009-5020. https://doi.org/10.3168/jds.2020-19405.

Welboren, A. C., L. N. Leal, M. A. Steele, M. A. Khan, and J. MartínTereso. 2019. Performance of ad libitum fed dairy calves weaned 
using fixed and individual methods. Animal 13:1891-1898. https:/ /doi.org/10.1017/S1751731119000181.

Wilcox, C. S., M. M. Schutz, M. R. Rostagno, D. C. Lay Jr., and S. D. Eicher. 2013. Repeated mixing and isolation: measuring chronic, intermittent stress in Holstein calves. J. Dairy Sci. 96:7223-7233. https://doi.org/10.3168/jds.2013-6944.

Wilms, J., H. Berends, and J. Martín-Tereso. 2019. Hypertonic milk replacers increase gastrointestinal permeability in healthy dairy calves. J. Dairy Sci. 102:1237-1246. https://doi.org/10.3168/jds .2018-15265.

Wilms, J. N., H. Berends, L. N. Leal, and J. Martín-Tereso. 2020. Determining the nutritional boundaries for replacing lactose with glucose in milk replacers for calves fed twice daily. J. Dairy Sci. 103:7018-7027. https://doi.org/10.3168/jds.2019-18034.

Winder, C. B., C. A. Bauman, T. F. Duffield, H. W. Barkema, G. P. Keefe, J. Dubuc, F. Uehlinger, and D. F. Kelton. 2018. Canadian National Dairy Study: Heifer calf management. J. Dairy Sci 101:10565-10579. https://doi.org/10.3168/jds.2018-14680.

Winder, C. B., K. J. Churchill, J. M. Sargeant, S. J. LeBlanc, A. M. O'Connor, and D. L. Renaud. 2019. Invited review: Completeness of reporting of experiments: REFLECTing on a year of animal trials in the Journal of Dairy Science. J. Dairy Sci. 102:4759-4771. https://doi.org/10.3168/jds.2018-15797.
Yohe, T. T., H. Berends, L. N. Leal, J. N. Wilms, M. A. Steele, and J. Martín-Tereso. 2021. Metabolic and performance responses to the replacement of lactose by fat in milk replacer formulations for dairy calves. Animal 15:100031. https://doi.org/10.1016/j.animal 2020.100031

Yohe, T. T., H. Schramm, R. R. White, M. D. Hanigan, C. L. M Parsons, H. L. M. Tucker, B. D. Enger, N. R. Hardy, and K. M. Daniels. 2019. Form of calf diet and the rumen. II: Impact on volatile fatty acid absorption. J. Dairy Sci. 102:8502-8512. https://doi .org/10.3168/jds.2019-16450.

Yu, Z.-T., C. Chen, and D. S. Newburg. 2013. Utilization of major fucosylated and sialylated human milk oligosaccharides by isolated human gut microbes. Glycobiology 23:1281-1292. https://doi.org/ $10.1093 /$ glycob/cwt065.

Zanton, G. I., and A. J. Heinrichs. 2005. Meta-analysis to assess effect of prepubertal average daily gain of Holstein heifers on first lactation production. J. Dairy Sci. 88:3860-3867. https://doi.org/ 10.3168/jds.S0022-0302(05)73071-X.

Zentrich, E., M. Iwersen, M. C. Wiedrich, M. Drillich, and D. KleinJöbstl. 2019. Effect of barn climate and management-related factors on bovine colostrum quality. J. Dairy Sci. 102:7453-7458. https://doi.org/10.3168/jds.2018-15645 